\title{
AVALIAÇÃO DE DANOS CAUSADOS PELO ENFEZAMENTO VERMELHO E ENFEZAMENTO PÁlIDO NA CULTURA DO MILHO
}

\author{
NELSON SidNEI MASSOLA JÚNIOR \\ Engenheiro Agrônomo
}

Orientador: Prof. Dr. IVAN P. BEDENDO

\begin{abstract}
Tese apresentada à Escola Superior de Agricultura
"Luiz de Queiroz", Universidade de São Paulo, para obtenção do título de Doutor em Agronomia, Área de Concentração: Fitopatologia.
\end{abstract}

\author{
P I R A C I C A B A \\ Estado de São Paulo - Brasil
}

Setembro de 1998 
Dados Internacionais de Catalogação na Publicação (CIP) DIVISĀO DE BIBLIOTECA E DOCUMENTAÇĀO - Campus "Luiz de Queiroz"/USP

Massola Júnior, Nelson Sidnei

Avaliaçăo de danos causados pelo enfezamento vermelho e enfezamento pálido na cultura do milho / Nelson Sidnei Massola Júnior. - - Piracicaba, 1998.

$75 \mathrm{p}$.

Tese (doutorado) - Escola Superior de Agricultura Luiz de Queiroz, 1998.

Bibliografia.

1. Doença de planta 2. Genotipo vegetal 3. Milho 4. Perda agricola 5. Relação planta- patógeno 1. Título 
Aos meus pais Nelson e Vilma, à minha irmã Cláudia e à minha avó Elisa, pelo incentivo e constante apoio, ofereço

A minha noiva Fernanda, exemplo de paciência $e$ compreensão,

dedico 


\section{AGRADECIMENTOS}

$\mathrm{O}$ autor manifesta seus agradecimentos a todos aqueles que, de alguma forma, contribuíram para a realização deste trabalho, em especial:

Ao Prof. Dr. Ivan P. Bedendo, pela orientação e apoio neste trabalho, pelos acertados conselhos na vida profissional e pessoal e pela gratificante amizade demonstrada a cada dia dessa convivência que já dura 10 anos.

Aos professores que co-orientaram este trabalho, $\operatorname{Prof}^{\mathrm{a}} \operatorname{Dr}^{\mathrm{a}}$ Lilian Amorim e Prof. Dr. João R. Spotti Lopes, respectivamente dos Departamentos de Fitopatologia e Entomologia da ESALQ, pelas valiosas contribuições e pela extrema disposição em auxiliar.

À Fundação de Amparo à Pesquisa do Estado de São Paulo (FAPESP), pela bolsa de estudo concedida para a realização desta pesquisa.

Aos professores Jorge A. M. Rezende e Luís E. A. Camargo, pelas facilidades concedidas para a execução dos testes ELISA e PCR. Ao professor Tasso Leo Krugner, pela revisão do Summary.

Aos demais professores do Departamento de Fitopatologia da ESALQ, pelos ensinamentos e convivência amigável.

Aos funcionários do Departamento de Fitopatologia: Marina, Jeferson, Heloísa, Rodolfo, Fernanda e, especialmente ao Sr. Pedro C. Arthuso e José Edivaldo Buriolla, pelo direto envolvimento nos ensaios e excelentes serviços prestados.

Aos colegas alunos e estagiários do Departamento de Fitopatologia: Matê, Bete, Cláudia, Nilceli, Sílvia, João, Marise, Cecília, Renato, Flávia, Luciana, Ângela, Leonardo, Renata, André, Elisa, Stella, Alexandre, Kátia, Denise, Juliana, Daniela, Regina, Raquel, Hélio, Fabiana e Zé Renato, pelas contribuições e por terem proporcionado um ambiente agradável de trabalho.

Ao Eng. Agr. MS Quelmo Silva de Novaes, amigo de todas as horas, pelo auxílio na condução dos ensaios.

À Eng. Agr. Célia Corrêa Malvas, pelo auxílio com os testes moleculares e pela amizade demonstrada durante o curso de Doutoramento. 
Aos professores Marcos Folegatti e José Branco de Miranda Filho, pela cessão das áreas experimentais na Fazenda Areão e Departamento de Genética, respectivamente.

Ao Eng. Agr. Cláudio Roberto Segatelli e funcionários do campo experimental do Departamento de Genética, pelo valioso auxílio na condução dos ensaios realizados nesse Departamento.

À Sementes Agroceres S/A, especialmente ao Eng. Agr. Dr. Osvaldo A. P. Pereira, pelas sugestões, e técnicos Romildo e Juliano, pelo auxílio na condução dos ensaios instalados em Jacarezinho-PR.

À Dinamilho Carol Ltda., especialmente ao Eng. Agr. MS Roberto Venceslau de Carvalho, pela condução do ensaio instalado em Jardinópolis-SP.

Ao Prof. Dr. Carlos Tadeu do Santos Dias, do Departamento de Matemática e Estatística da ESALQ, pela assistência nas análises estatísticas. 


\section{SUMÁRIO}

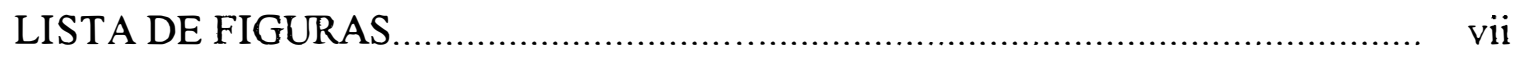

LISTA DE TABELAS............................................................................ viii

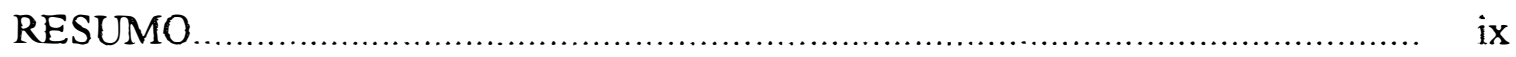

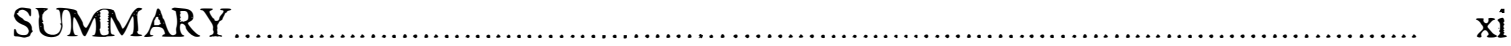

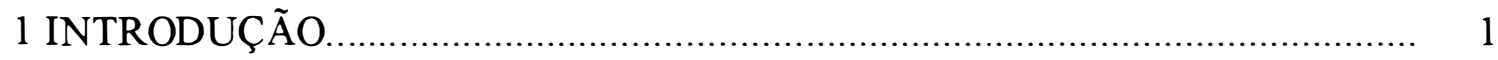

2 REVISÃO DE LITERATURA.................................................................. 3

2.1 Produção de milho no Brasil............................................................................. 3

2.2 Enfezamento vermelho e enfezamento pálido do milho............................ 4

2.2.1 Importância e distribuição geográfica.............................................. 4

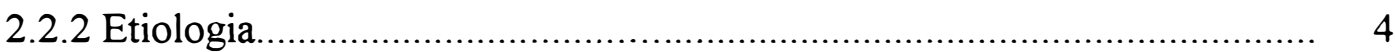

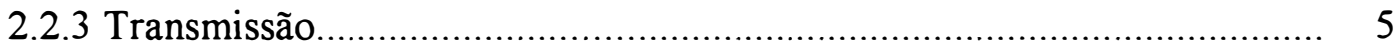

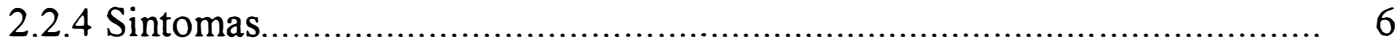

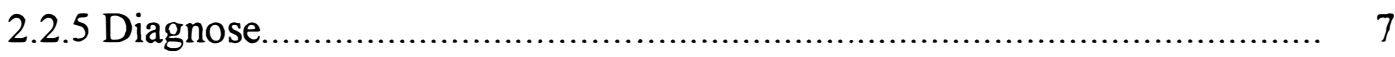

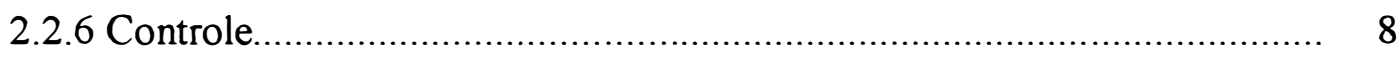

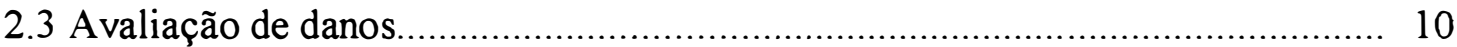

3 QUANTIFICAÇÃO DE DANOS CAUSADOS PELO ENFEZAMENTO

VERMELHO E ENFEZAMENTO PÁLIDO DO MILHO EM CONDIÇÕES DE

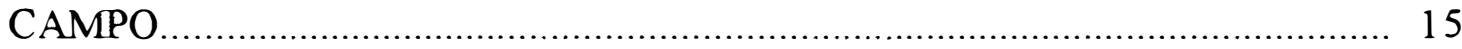

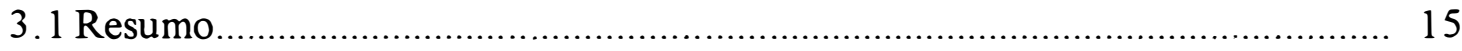

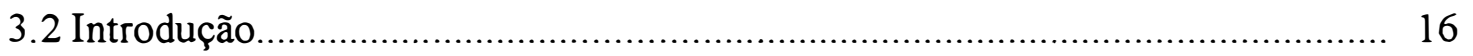

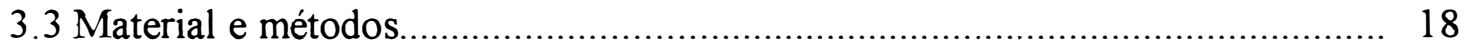

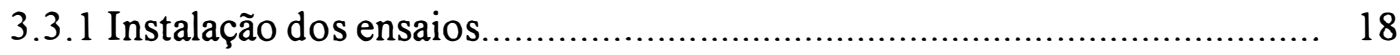

3.3.2 Avaliação das doenças e das populações de D. maidis .......................... 19

3.3.3 Avaliação da produção e dos danos............................................. 20

3.3.4 Efeito da época de manifestação de sintomas sobre os danos................ 21

3.3.5 Efeito de compensação entre plantas doentes e sadias........................ 21

3.3.6 Análises dos resultados................................................................ 22

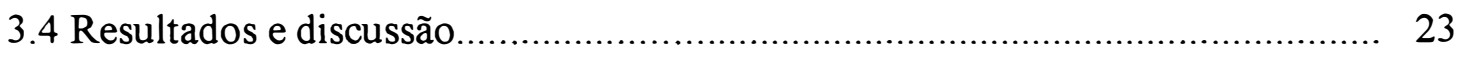

3.4.1 Diagnose dos agentes dos enfezamentos vermelho e pálido................ 23 
3.4.2 Curvas de progresso das doenças............................................... 24

3.4.3 Relação entre danos e incidências.................................................... 27

3.4.4 Relação entre danos e AACPD....................................................... 29

3.4.5 Efeito da incidência dos enfezamentos vermelho e pálido sobre o

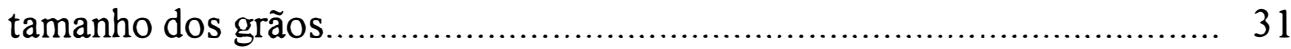

3.4.6 Efeito da época de manifestação de sintomas sobre os danos................ 32

3.4.7 Efeito de compensação entre plantas doentes e sadias......................... 35

3.4.8 Populações de D. maidis e incidências dos enfezamentos vermelho e pálido

4 EFEITO DA ÉPOCA DE INOCULAÇÃO DE Spiroplasma kunkelii NA PRODUÇÃO DE PLANTAS DE MILHO ..................................................... 40

4.1 Resumo 40

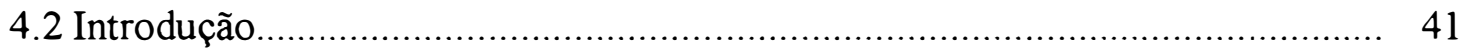

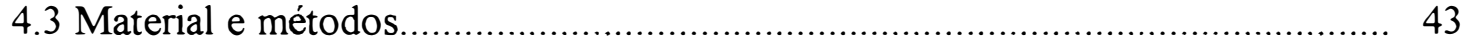

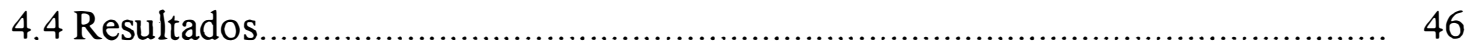

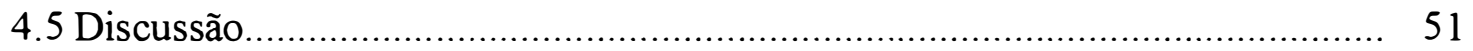

5 MULTIPLICAÇÃO DE FITOPLASMA E ESPIROPLASMA E DANOS EM GENÓTIPOS RESISTENTE E SUSCETÍVEL DE MILHO ............................. 54

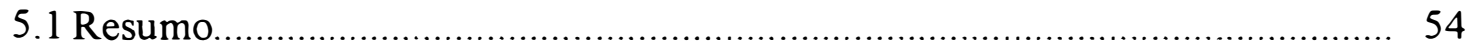

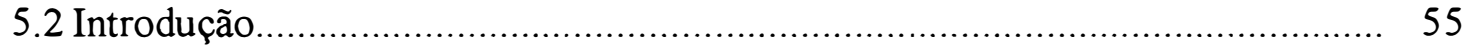

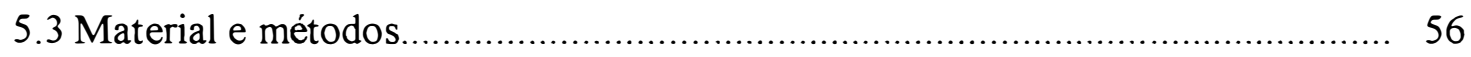

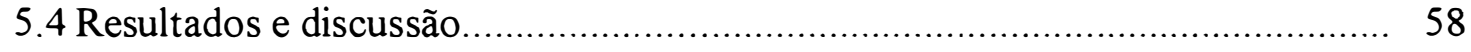

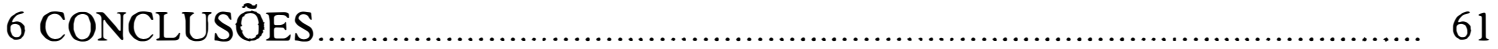

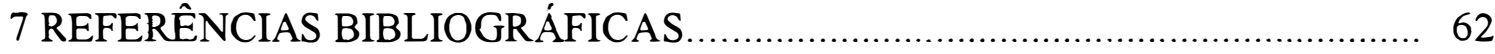




\section{LISTA DE FIGURAS}

Página

1 Curvas de progresso dos enfezamentos vermelho e pálido do milho para os híbridos Dina-933e e XL-510, para os ensaios realizados na safra 96/97 em Piracicaba...

2 Danos na produção e no peso de 1000 grãos de milho em função da incidência dos enfezamentos vermelho e pálido no estádio fenológico 7, para os híbridos Dina-933e e XL-510 ( $\mathrm{Y}=$ dano na produção $(\%)$ e $\mathrm{X}=$ incidência (\%))

3 Danos na produção e no peso de 1000 grãos de milho em função da área abaixo da curva de progresso da epidemia dos enfezamentos vermelho e pálido (AACPD). Para o híbrido Dina-933e foram utilizados os ensaios 08 a 11 e para o híbrido XL-510 foram utilizados os ensaios 12 a 15 (Y = dano na produção (\%) e $\mathrm{X}=\mathrm{AACPD})$.

4 Variação nas porcentagens de grãos retidos nas peneiras de 9,52 e 7,14 mm para os híbridos de milho Dina-933e e XL-510, em função das incidências dos enfezamentos vermelho e pálido no estádio fenológico 7 .

5 Danos na produção dos híbridos de milho Dina-933e e XL-510 em função da época de aparecimento dos sintomas dos enfezamentos vermelho e pálido no campo ( $Y=$ dano na produção $(\%)$ e $X=$ semana)

6 Efeito da época de inoculação do híbrido de milho XL-510 com Spiroplasma kunkelii na altura de plantas (A) e número de espigas/planta (B) (Cada ponto representa a média de 4 repetições. As barras representam o erro padrão)

7 Efeito da época de inoculação do híbrido de milho XL-510 com Spiroplasma kunkelii na produção (A) e no peso de 1000 grãos (B) (Cada ponto representa a média de 4 repetições. As barras representam o erro padrão)

8 Efeito da época de inoculação do híbrido de milho XL-510 com Spiroplasma kunkelii no tamanho de grãos (Cada ponto representa a média de 4 repetições) 


\section{LISTA DE TABELAS}

Página

1 Ensaios realizados com os híbridos de milho Dina-933e e XL-510 para avaliação de danos devido aos enfezamentos vermelho e pálido...

2 Funções de danos na produção para os enfezamentos vermelho e pálido em diferentes estádios fenológicos do milho

3 Correlações entre variação nas porcentagens de grãos retidos em diferentes peneiras e as incidências dos enfezamentos vermelho e pálido no estádio fenológico 7, para os híbridos Dina-933e e XL-510.

4 Produção média das plantas centrais das seqüências sadia-sadia-sadia (SSS), sadia-sadia-doente (SSD) e doente-sadia-doente (DSD) para os híbridos Dina-933e e XL-510

5 Coeficientes de correlação (r) entre população de $D$. maidis e incidências dos enfezamentos vermelho e pálido em diferentes semanas após a emergência, para o híbrido Dina-933e.

6 Coeficientes de correlação (r) entre população de $D$. maidis e incidências dos enfezamentos vermelho e pálido em diferentes semanas após a emergência, para o híbrido XL-510..

7 Épocas de inoculação de plantas de milho do híbrido XL-510 com Spiroplasma kunkelii para determinação dos efeitos em componentes da produção

8 Manifestação de sintomas e detecção de fitoplasma e de espiroplasma em genótipos suscetível e resistente de milho

9 Efeito do fitoplasma e do espiroplasma, isolada e cojuntamente, na produção e na altura de plantas de genótipos suscetível e resistente de milho. 


\title{
AVALIAÇÃO DE DANOS CAUSADOS PELO ENFEZAMENTO VERMELHO E ENFEZAMENTO PÁLIDO NA CULTURA DO MLHO
}

\author{
Autor: NELSON SIDNEI MASSOLA JÚNIOR \\ Orientador: Prof. Dr. IVAN P. BEDENDO
}

\section{RESUMO}

O efeito da incidência de enfezamento vermelho e pálido sobre a produção, o peso de mil grãos e o tamanho de grãos de dois híbridos suscetíveis (XL-510 e Dina933e) foi avaliado em 15 ensaios de campo. Os ensaios foram conduzidos durante os anos agrícolas de 95/96 e 96/97, em Piracicaba-SP, Jardinópolis-SP e Jacarezinho-PR. Também foi avaliado o efeito da época de manifestação dos sintomas pelas plantas sobre a produção e a correlação entre população da cigarrinha vetora (Dalbulus maidis) e incidências das doenças. Numa segunda etapa, o efeito de inoculações seriadas com Spiroplasma kunkelii, em diferentes estádios de desenvolvimento do híbrido XL-510, foi avaliado em condições de telado, buscando-se relacionar época de infecção e danos provocados. Por último, os híbridos de milho AG-951 (resistente) e XL-510 (suscetível), foram experimentalmente inoculados, em condições de casa de vegetação, com fitoplasma, espiroplasma e fitoplasma + espiroplasma, com a finalidade de verificar a multiplicação e os efeitos dos patógenos sobre plantas pertencentes a esses diferentes genótipos. Em todos esses ensaios, a evolução dos sintomas foi avaliada semanalmente e a produção quantificada ao final do experimento. Todas as inoculações artificiais foram realizadas por meio de insetos vetores (D. maidis) criados em laboratório e infectados por meio de aquisição em planta fonte. Os resultados mostraram que quanto maior foi a incidência de enfezamento no campo, maiores foram os danos em todos as variáveis avaliadas. Funções de danos, estimadas com base na incidência avaliada no estádio de grãos pastosos, revelaram reduções na produção de $0,8 \%$ para cada $1 \%$ de incremento na incidência, para ambos os híbridos testados. Essa mesma variação na incidência, provocou danos no peso de 1000 grãos de $0,8 \%$ e $0,4 \%$, para os híbridos Dina-933e e 
$\mathrm{XL}-510$, respectivamente. O tamanho dos grãos, revelado pelo teste de retenção em peneiras com diferentes diâmetros de malhas, também foi negativamente influenciado pela doença. A área abaixo da curva de progresso da doença (AACPD) foi uma boa variável para estimar os danos. Quanto mais precoce foi a manifestação dos sintomas pelas plantas no campo, maiores foram os danos para ambos os híbridos, porém não houve correlação entre população do vetor com a incidência de ambos os tipos de enfezamento. As inoculações seriadas com S. kunkelii no híbrido XL-510 revelaram que, tanto a produção como a qualidade dos grãos foram mais severamente afetadas quanto mais precoce foi a inoculação. Para o intervalo entre os dias 10 e 38 após a emergência, cada dia de atraso na inoculação representou $0,5 \%$ de aumento na produção, entretanto, para o intervalo entre os dias 38 e 66 , esse aumento foi de $1,5 \%$. Os resultados do último ensaio mostraram que foi possível detectar o espiroplasma e o fitoplasma somente no híbrido suscetível, indicando que no híbrido resistente não ocorreu multiplicação dos patógenos. Manifestação de sintomas e redução na produção foram registrados também somente para o híbrido suscetível, tendo sido constatado que o fitoplasma mostrou-se mais agressivo que o espiroplasma, induzindo o aparecimento de sintomas mais precocemente e causando os maiores danos. 


\title{
EVALUATION OF YIELD LOSSES CAUSED BY THE MAIZE BUSHY STUNT AND CORN STUNT DISEASE IN CORN
}

\author{
Author: NELSON SIDNEI MASSOLA JÚNIOR \\ Adviser: Prof. Dr. IVAN P. BEDENDO
}

\section{SUMMARY}

The effect of Corn Stunt and Maize Bushy Stunt Disease on yield, 1000-kernel weight, and percentage of kernels in different sizes was evaluated under field conditions for the susceptible hybrids of corn XL-510 and Dina-933e. Fifteen surveys were carried out during the growing seasons of 95/96 and 96/97, in Piracicaba-SP, Jardinópolis-SP, and Jacarezinho-PR. It was also evaluated the effect of time of symptom expression on yield and the relationship between the population of the insect vector and incidence of both diseases. In a second step, it was evaluated the effect of serial inoculations with Spiroplasma kunkelii on some yield components for the hybrid XL-510, under screenhouse conditions, in order to relate time of infection and yield. Finally, the corn hybrids AG-951 (resistant) and XL-510 (susceptible) were experimentally inoculated, under greenhouse conditions, with spiroplasma, phytoplasma, and spiroplasma + phytoplasma, in order to verify the multiplication and the effects of the pathogens on these genotypes. In all of these trials, the evolution of the symptoms was evaluated weekly and the yield was quantified at the end of the experiment. All artificial inoculations were performed by infective leafhoppers (Dalbulus maidis) grown in the laboratory. The greater the incidence of the disease in the field, the greater was the losses for all evaluated variables. Yield loss models, fitted on the basis of the final disease incidence in the field, revealed a loss of $0,8 \%$ for each increase of $1 \%$ in the incidence for both of the hybrids. The same variation in incidence led to reductions on the 1000kernel weight of $0,8 \%$ and $0,4 \%$ for the hybrids Dina-933e and XL-510, respectively. The disease also negatively influenced kernel size. Area under disease progress curve (AUDPC) was a good variable for estimating losses. The earlier the symptom expression 
in the plants, the more severe were the losses for both of the hybrids. It was not observed correlation between disease incidence and D. maidis levels. When corn plants of the hybrid XL-510 were inoculated with S. kunkelii in the screenhouse, the earlier the inoculation time, the more severe was the reduction in grain production and quality. For the interval between days 10 and 38 after crop emergence, for each day that infection was delayed, there was an increase of $0.5 \%$ in yield. However, for the period of 38-66 days, there was an increase of $1.5 \%$ in yield. Results of the lattest test showed that it was possible to detect spiroplasma and phytoplasma only in the susceptible hybrid, indicating that the resistant one did not multiply the pathogens. Symptom expression and yield reductions were also reported only in the susceptible hybrid. The phytoplasma was more aggressive than the spiroplasma, leading to earlier symptom expression and being responsible for the highest losses. 


\section{INTRODUÇÃO}

O milho é uma das mais importantes culturas do Brasil. Sua área de plantio vem aumentando, tanto na safra de verão quanto nas épocas não tradicionais, como por exemplo, nos meses de fevereiro a abril. Estes plantios tardios, conhecidos como "safrinha", aliados à adoção de irrigação, proporcionam a presença da cultura no campo durante o ano todo em certas regiões. Esta nova condição, de plantios sucessivos, impôs à cultura alguns problemas de caráter fitopatológico. Doenças que antes possuíam importância secundária, constituem, agora, problemas sérios, como por exemplo aquelas transmitidas por insetos (Waquil et al., 1996; Oliveira et al., 1997). Com a expansão da cultura para áreas e épocas não tradicionais de cultivo, torna-se fundamental o conhecimento do comportamento dos patossistemas nessa nova condição, para que se possa recomendar um manejo eficiente da cultura.

Os enfezamentos do milho, tanto o vermelho como o pálido, são duas dessas doenças que vêm apresentando importância crescente. Os agentes causais, respectivamente um fitoplasma e um espiroplasma podem provocar infecção isolada ou conjunta, sendo transmitidos pela cigarrinha do milho (Dalbulus maidis). Os dois patógenos envolvidos, assim como a cigarrinha vetora, são encontrados somente em espécies do gênero Zea e Tripsacum, indicando alto nivel de especialização (Nault, 1990). Isso explica as maiores incidências das doenças em regiões onde se faz plantios sucessivos de milho (Hruska et al., 1996; Oliveira \& Oliveira, 1998).

Estudos epidemiológicos sobre estas doenças são raros no Brasil e os danos por elas causados não estão bem caracterizados. Entretanto, sabe-se que seu potencial em causar redução na produção é grande. Relatos de prejuizos de até $100 \%$ podem ser 
encontrados na literatura, como por exemplo, nos trabalhos de Scott et al.(1977) e Oliveira et al. (1998).

Segundo Bergamin Filho (1995), estimativas confiáveis dos prejuizos causados pelos patógenos constituem-se num pré-requisito para o desenvolvimento de qualquer programa bem sucedido de controle de doenças de plantas, independente do método a ser utilizado. É obrigatório que se conheça o valor do prejuízo, pois só assim, em conjunção com o custo do controle, uma decisão racional e econômica poderá ser tomada. Além de fornecer subsídios para orientar estratégias de controle, Campbell \& Madden (1990) consideram importante o conhecimento dos prejuizos para a definição de prioridades de pesquisa e como base para decisões políticas e governamentais a níveis local, estadual, nacional e até internacional.

O presente trabalho teve por objetivo verificar os efeitos dos enfezamentos vermelho e pálido em alguns componentes da produção de plantas de milho. No capitulo 3 , por meio de ensaios em campo, foram estudadas as relações entre os níveis de doença e reduções na produção e na qualidade dos grãos e entre população do vetor e níveis de doença. No capítulo 4 , foi verificado, em condições controladas, o efeito da época da infecção com Spiroplasma kunkelii sobre os danos e, no capitulo 5, foram avaliados os danos causados por ambos os patógenos em dois genótipos de milho, um resistente e outro suscetivel. A redução na produção foi analisada como variável dependente da incidência da doença, da época de infecção da planta ou do patógeno inoculado. Além disso, em todos os ensaios, procurou-se associar, através de métodos de deteç̧ão, os agentes causais com os sintomas observados nas plantas doentes. 


\section{REVISÃO DE LITERATURA}

\subsection{Produção de milho no Brasil}

O milho é uma das principais culturas do Brasil, contribuindo com mais de um terço de toda a produção nacional de cereais e oleaginosas (Pinazza, 1993). A cultura encontra-se amplamente distribuída no Brasil e vem mostrando significativos aumentos, tanto na produtividade quanto na área cultivada (Almeida, 1993; Magalhães et al., 1995). A área plantada com a cultura apresentou um aumento de $20 \%$ nos últimos 20 anos, passando dos 10 milhões de hectares em 1973 para os atuais 12 milhões de hectares. Nesse mesmo período, a produção teve um aumento de mais de $100 \%$, saltando de 14 para 30 milhões de toneladas em 1993 (Anuário estatístico do Brasil, 1975; Anuário estatístico do Brasil, 1995). Este espetacular aumento na produção foi função, além da utilização de híbridos mais produtivos e técnicas mais adequadas de condução da cultura, da realização de plantios adicionais, em épocas não convencionais de cultivo. Os plantios "safrinha", como são conhecidos os cultivos de milho após a retirada da cultura de verão, apresentaram significativo aumento na área plantada nos últimos anos. Atualmente, essa nova modalidade de plantio perfaz cerca de 1,4 milhão de hectares e contribui com 3,3 milhões de toneladas de grãos, o que representa aproximadamente $12 \%$ da produção nacional de milho. Os principais estados produtores são Paraná e São Paulo, respectivamente com $37 \%$ e $27 \%$ do total da área plantada com milho "safrinha" no Brasil (Garcia, 1997). 


\subsection{Enfezamento vermelho e enfezamento pálido do milho}

\subsubsection{Importância e distribuição geográfica}

O primeiro registro foi feito na década de 40, no estado norte-americano do Texas (Altstatt, 1945). Atualmente, além dos Estados Unidos, existem relatos feitos no México (Davis, 1973; Gordon et al., 1985; Bajet \& Renfro, 1989), Nicarágua (Hruska et al., 1996), Venezuela (Lastra \& Trujillo, 1976), Peru (Nault et al., 1979; Nault et al., 1981), Paraguai (Lezcano \& Machado, 1997) e Argentina (Lenardon et al., 1993). No Brasil, as doenças são conhecidas desde o início da década de 70 (Costa et al., 1971), quando eram consideradas de importância secundária. Entretanto, já naquela época alertava-se que poderiam causar sérios prejuízos caso o milho fosse plantado tardiamente. Essa tendência em causar maiores danos em plantios tardios já havia sido verificada por Altstatt (1945) desde a primeira descrição feita por este autor. A partir de então, ambos os enfezamentos têm causado epidemias em diversos países, como Estados Unidos (Bradfute et al., 1981), Argentina (Lenardon et al., 1993), Nicarágua (Hruska et al., 1996) e Brasil (Oliveira et al., 1998). Os prejuizos associados às doenças podem chegar a 100\%, dependendo da suscetibilidade dos genótipos plantados (Scott et el., 1977; Oliveira et al., 1998).

\subsubsection{Etiologia}

Desde seu primeiro relato, acreditou-se que a etiologia fosse de causa viral (Maramorosch, 1958). Somente por volta de 1970 descobriu-se que os agentes causais eram dois molicutes, sendo o enfezamento pálido ("Corn Stunt") causado pelo espiroplasma denominado Spiroplasma kunkelii e o enfezamento vermelho ("Maize Bushy Stunt") associado a um organismo do tipo micoplasma, atualmente chamado de fitoplasma (Granados, 1969; Chen \& Granados, 1970; Davis et al., 1972; Chen \& Liao, 1975; Williamson \& Whitcomb, 1975). Ambos são organismos sem parede celular, com

uma membrana unitária envolvendo o citoplasma. São restritos ao floema das plantas 
doentes e sensiveis à tetraciclina, porém não à penicilina (Bedendo et al., 1995; Agrios, 1997).

O espiroplasma causador do enfezamento pálido foi visto pela primeira vez em plantas infectadas no ano de 1972 (Davis et al., 1972). Esta foi a primeira constatação de organismos com morfologia helicoidal em plantas. Um ano mais tarde, o termo "spiroplasma" foi proposto para designar tais organismos (Davis \& Worley, 1973). Somente em 1986, após estudos detalhados de morfologia, requerimentos nutricionais, bioquímica, sorologia e análise genômica, o nome da espécie foi homologado como sendo Spiroplasma kunkelii (Whitcomb et al., 1986). O isolamento em meio de cultura e o preenchimento dos postulados de Koch para esse microrganismo foi realizado simultaneamente por duas equipes, em 1975 (Chen \& Liao, 1975; Williamson \& Whitcomb, 1975). Nos anos subseqüentes, diversos estudos sobre isolamento e composição do meio de cultura foram realizados (Jones et al., 1977; Liao \& Chen, 1977; Davis et al., 1984; Lee \& Davis, 1984; Alivizatos, 1988; Lee \& Davis, 1989).

Ao contrário do $S$. kunkelii, o fitoplasma associado ao enfezamento vermelho ainda não foi cultivado in vitro. Esse organismo foi relatado pela primeira vez em plantas de milho, por meio de microscopia eletrônica, em 1969 (Granados, 1969). Como não pode ser cultivado, os postulados de Koch ainda não foram preenchidos e os estudos de caracterização desse agente ficam restritos à testes biológicos envolvendo hospedeiros e vetores. Entretanto, o advento das técnicas moleculares envolvendo ácidos nucléicos tem proporcionado grandes avanços na identificação e caracterização dos fitoplasmas (Davis, 1995a). Recentemente foi constatado, por meio de PCR e RFLP, que o fitoplasma que causa o enfezamento vermelho no Brasil é geneticamente similar ao agente da doença conhecida como "Maize Bushy Stunt" (MBS) nos EUA (Bedendo et al., 1997).

\subsubsection{Transmissão}

Ambos os patógenos são transmitidos pela cigarrinha do milho (Dalbulus maidis DeLong \& Wolcott), de maneira persistente propagativa (Nault, 1980). Este tipo de relação entre patógeno e vetor é, geralmente, caracterizado pela existência de periodos 
bem definidos envolvendo esta associação. Assim, o período de aquisição é definido como o tempo necessário para que o vetor adquira o patógeno, ao se alimentar numa planta fonte infectada; o período de incubação ou de latência é o tempo necessário para que o patógeno colonize os tecidos internos do vetor, até atingir as glândulas salivares, quando o inseto estará apto a transmiti-lo; o período de inoculação corresponde ao tempo necessário para que o vetor inocule o patógeno numa planta sadia; finalmente, o período de retenção se refere ao tempo em que o inseto permanece capaz de transmitir o patógeno (Nault, 1997). No caso da associação entre os agentes causais de ambos os enfezamentos e a cigarrinha $D$. maidis, os períodos de aquisição, incubação e inoculação, variam, respectivamente, de 4 a 7 dias, 13 a 24 dias e 2 a 7 dias. O período de retenção é bastante longo, sendo que o inseto normalmente transmite os agentes por toda a vida. Entretanto, a eficiência na transmissão costuma decrescer em função da idade do vetor (Davis, 1974; Tsai, 1979; Nault, 1980; Madden \& Nault, 1983). A duração dos períodos de aquisição, incubação e inoculação apresenta influência na proporção final de insetos infectivos e na transmissão. De modo geral, à medida que se aumentam os períodos de aquisição e incubação, aumenta-se a proporção de insetos infectivos e, à medida que se aumenta o período de inoculação, ocorre um aumento na taxa de transmissão (Alivizatos \& Markham, 1986; Legrand \& Power, 1994). Além da cigarrinha D. maidis, que é o principal vetor, tem sido demonstrado, experimentalmente, que outras espécies são capazes de transmitir, com eficiências variáveis, os agentes dessas doenças. Estas espécies incluem: Dalbulus eliminatus, D. gelbus, D. guevarai, D. quinquenotatus, D. tripsacoides, Baldulus tripsaci, Exitianus exitiosus, Graminella nigrifons e Stirellus bicolor (Granados \& Whitcomb, 1971; Choudhury \& Rosenkranz, 1973; Nault, 1980; Madden \& Nault, 1983).

\subsubsection{Sintomas}

Os sintomas iniciais de infeção por espiroplasma ou fitoplasma se traduzem por clorose nas margens das folhas do cartucho, com algum grau de avermelhamento das pontas das folhas mais velhas. A partir daí, a literatura registra diferenças na 
sintomatologia entre plantas infectadas com espiroplasma (enfezamento pálido) e fitoplasma (enfezamento vermelho). Sintomas mais adiantados do enfezamento pálido aparecem como pontos e estrias cloróticas bem delimitadas, próximas à base das folhas. Por ouro lado, sintomas de avermelhamento foliar e perfilhamento da planta são associados ao fitoplasma. Alguns outros sintomas, como redução no porte da planta e proliferação de espigas são atribuídos a ambos os patógenos indistintamente (Shurtleff, 1986). Entretanto, Nault (1980) demonstrou que o quadro sintomatológico das plantas afetadas pelos enfezamentos, além dos agentes causais, depende do genótipo do hospedeiro e das condições ambientes. Com exceção dos sintomas de estrias cloróticas na base das folhas, que estão invariavelmente associados ao espiroplasma, os demais sintomas não permitem uma associação segura com o agente causal. Confirmando essa constatação, Bajet \& Renfro (1989), verificaram a presença de $S$. kunkelii em plantas exibindo sintomas de avermelhamento ou amarelecimento foliar.

\subsubsection{Diagnose}

Devido à complexidade na sintomatologia, a diagnose precisa dos enfezamentos pálido e vermelho necessitam de testes mais refinados. Dessa forma, alguns estudos têm revelado a utilidade da microscopia ótica, associada ao uso de determinados corantes, para fins de diagnose (Deeley et al., 1979; Overman et al., 1992). Entretanto, estes estudos apenas confirmam a infecção por molicutes, sem no entanto revelar se o agente é o espiroplasma ou o fitoplasma. A microscopia eletrônica de transmissão ou varredura, pelo seu grande poder de resolução, tem auxiliado na detecção precisa desses organismos (Kitajima \& Costa, 1979; Bradfute et al., 1981; Kitajima \& Nazareno, 1985; Massola Júnior \& Kitajima, 1997). Entretanto, a distribuição irregular dos patógenos nos tecidos da planta infectada (Davis, 1995b; Gussie et al., 1995), aliada à pequena secção de tecido utilizada, tornam a microscopia eletrônica um método pouco prático para diagnose em larga escala. Dessa forma, outros métodos de diagnose foram desenvolvidos para essa finalidade. 
Devido ao fato do espiroplasma ser cultivável em meios sintéticos, torna-se fácil a obtenção de antisoro para este agente. Assim sendo, o teste ELISA ("enzyme-linked immunosorbent assay") tem sido largamente utilizado para a sua detecção (Nault et al., 1979; Raju \& Nyland, 1981; Eden-Green, 1982; Gordon et al., 1985; Lopes et al., 1997; Oliveira et al., 1998). Para os fitoplasmas, porém, o teste ELISA não tem sido muito empregado devido à dificuldade de obtenção de antisoro. Entretanto, alguns estudos envolvendo antisoro monoclonal têm permitido diagnoses seguras (Lin \& Chen, 1985; Chen \& Jiang, 1988).

Desde a descoberta dos fitoplasmas (previamente conhecidos como "mycoplasmalike organisms" - MLOs) por uma equipe de pesquisadores japoneses, em 1967, os estudos para diagnose desses agentes de doenças de plantas têm sido feitos por meio de microscopia eletrônica e testes biológicos, como por exemplo, gama de hospedeiros e vetores, sintomas em diferentes plantas, etc. Entretanto, as propriedades biológicas desses organismos podem levar a conclusões enganosas. As modernas técnicas biotecnológicas, particularmente aquelas envolvendo amplificação de determinadas seqüências do RNA ribossômico, têm auxiliado a solucionar esse problema (Davis, 1995a). A técnica de PCR (“polymerase chain reaction"), por ser relativamente simples e muito sensível, tem sido bastante utilizada por diversos pesquisadores, com a finalidade de detectar fitoplasmas em plantas e vetores (Davis \& Lee, 1993; Vega et al., 1993; Lee et al., 1993; Harrison et al., 1996; Bedendo et al., 1997; Lopes et al., 1997).

\subsubsection{Controle}

Os plantios tardios, chamados de "safrinha", são, geralmente, mais afetados por essas doenças, em função da ocorrência de altas populações do vetor durante os meses de março e abril (Waquil et al., 1997). Dessa forma, uma das medidas de controle preconizadas consiste em evitar este tipo de plantio. No entanto, o milho "safrinha" é uma prática amplamente adotada nas principais regiões produtoras do Brasil. Assim, o uso de genótipos resistentes tem sido a forma mais recomendada para minimizar os prejuizos causados pelas duas formas do enfezamento (Ullstrup, 1978; Shurtleff, 1986; 
Pereira, 1997). A resistência de genótipos de milho aos enfezamentos foi estudada por alguns pesquisadores por volta de 1970 e parece ser condicionada por vários genes. Grogan \& Rosenkranz (1968) verificaram que não houve dominância para resistência ou suscetibilidade ao enfezamento, porém os efeitos aditivos foram bastante evidentes. $\mathrm{Da}$ mesma forma, Nelson \& Scott (1973), através de cruzamentos dialélicos entre 5 linhagens suscetíveis e 5 resistentes, constataram que os efeitos aditivos na herança da resistência ao enfezamento foram muito mais pronunciados que a dominância. Numa escala de avaliação de 1 (resistente) a 6 (altamente suscetível), os autores obtiveram valores médios de 1,6, 2,4 e 3,5 para os cruzamentos resistente $\mathrm{X}$ resistente, resistente $\mathrm{X}$ suscetível e suscetível $\mathrm{X}$ suscetível, respectivamente. Num outro estudo, Scott \& Rosenkranz (1974) demonstraram que os genes que condicionam resistência ao enfezamento e ao mosaico anão do milho não são os mesmos. A resistência a estas duas doenças foi herdada independentemente.

Além do uso de genótipos resistentes, existem alguns estudos sobre controle do enfezamento baseados em outras medidas. Medidas culturais de controle têm sido estudadas através de alterações no nível de nitrogênio e na densidade de plantio, bem como através do uso de outras culturas em consórcio com o milho. Estas medidas baseiam-se na hipótese de que, tanto o nível de nitrogênio e a densidade de plantio, quanto a presença de uma cultura intercalar, modificam o ambiente de cultivo, influenciando na abundância, na atividade e no movimento dos insetos vetores. Consequentemente, a dispersão dos patógenos veiculados por $D$. maidis também seria influenciada. Entretanto, os poucos estudos realizados com a finalidade de investigar esta hipótese não têm mostrado efeitos pronunciados na redução da incidência do enfezamento. Em dois estudos realizados na Nicarágua (Power, 1987; Power, 1989), foram verificadas tendências em encontrar menores populações de $D$. maidis em parcelas com níveis mais baixos de nitrogênio e com maiores densidades de plantio. Nessas parcelas, a incidência de enfezamento também apresentou tendência em ser menor, porém, a análise estatística dos resultados mostrou que muitas destas tendências não foram significativas. Um outro estudo, conduzido na Costa Rica (Castro et al., 1992), mostrou que, nem a densidade de plantio nem a presença de uma cultura intercalar 
apresentaram influência marcante no movimento de $D$. maidis e na disseminação de patógenos veiculados por este vetor.

O controle químico do inseto vetor foi estudado no início da década de 70 , através de inseticidas sistêmicos aplicados no sulco de plantio (Bhirud \& Pitre, 1972). Entre os inseticidas testados, carbofuran foi o mais eficiente, tanto em casa de vegetação quanto no campo. $\mathrm{O}$ controle de D. maidis com este inseticida, no campo, proporcionou uma redução de cerca de $84 \%$ na incidência de plantas com enfezamento. Embora Oliveira et al. (1997) citem que é possível o controle químico de D. maidis, particularmente em campos de produção de sementes, não se conhecem estudos desta natureza em nossas condições.

\subsection{Avaliação de danos}

Segundo Campbell \& Madden (1990) e Bergamin Filho (1995), antes de se iniciar um programa visando o controle de doenças de plantas, é necessário que se conheça previamente os prejuízos causados pelos patógenos, independente do método de controle a ser adotado. O conhecimento dos prejuízos é fundamental para que se possa tomar uma decisão racional e econômica. Um programa amplo de quantificação de danos envolve um estudo detalhado das relações entre intensidade da doença $e$ as correspondentes reduções em produção e inclui a patometria (medição de níveis de doença), a epidemiologia e o desenvolvimento de modelos para estimar as reduções de produção. Relações entre intensidade de doença e reduções de produção podem ser estimadas através da função de dano (relação injúria-dano) e da função de perdas (relação dano-perda).

A estratégia geral de estimativa de danos envolve dois passos principais: (i) o monitoramento da doença através da incidência (\% de plantas ou partes de planta afetadas) e/ou severidade (\% da área ou volume afetados), com avaliação da produção final; e (ii) a construção de modelos para estimar danos (Bergamin Filho \& Amorim, 1991). 
Propostas de construção de modelos capazes de estimar danos, a partir dos parâmetros incidência e severidade, têm sido feitas apenas recentemente (Large, 1966; James, 1974; Horsfall \& Cowling, 1978; Chiarappa ${ }^{1}$, citado por Bergamin Filho \& Amorim, 1991; Teng, 1987; Waggoner \& Berger, 1987). De modo geral, os modelos correlacionam a quantidade de doença com a produção final, servindo para estimar precocemente os danos que podem ocorrer na cultura.

No caso das doenças viróticas sistêmicas (patossistemas semelhantes aos enfezamentos do milho), a variável mais indicada para a monitoramento da doença é a incidência. A severidade pode ser utilizada somente para viroses que apresentam sintomas localizados, uma vez que sintomas sistêmicos não permitem uma clara diferenciação entre áreas doentes e sadias da planta infectada (Bergamin Filho \& Amorim, 1991). Para as doenças viróticas, existem vários relatos indicando que a redução na produtividade é altamente correlacionada à incidência da doença $\left(\mathrm{Bos}^{2}\right.$, citado por Bergamin Filho \& Amorim, 1991; Waquil et al. 1996).

Entre os métodos relatados na literatura para a obtenção de dados para estimativa de danos, os mais empregados, segundo Bergamin Filho \& Amorim (1996), são o método da parcela experimental e o método da planta individual. No primeiro método, os danos são calculados com base na diferença de produção entre parcelas mantidas sadias e parcelas com diferentes níveis de doença. Os diferentes níveis de doença podem ser obtidos em função de diferentes épocas de inoculação, quantidade de inóculo inicial, uso de variedades resistentes ou utilização de diferentes dosagens e/ou número de aplicações de fungicidas. No método da planta individual, um determinado número de plantas são marcadas, avaliadas para intensidade de doença e colhidas quando atingem a maturidade. Entre as plantas marcadas, recomenda-se que exista a maior variação possível na intensidade de doença, incluindo plantas sadias que servirão como controles. No final, cada planta é considerada como um dado nas análises de regressão. Este último método apresenta, em relação ao anterior, as vantagens de ocupar menos

\footnotetext{
${ }^{1}$ CHIARAPPA, L. Establishing the crop loss profile. In: FAO. Crop loss assessment methods. Farnham Royal: Commonwealth Agricultural Bureaux, 1981. p.21-24. Supplement, 3.

${ }^{2}$ BOS, L. Assessment of crop losses caused by viruses. In: FAO. Crop loss assessment methods. Famham Royal: Commonwealth Agricultural Bureaux, 1981. p.79-84. Supplement, 3.
} 
espaço, apresentar variações contínuas na intensidade de doença e não necessitar do emprego de fungicidas.

Os principais modelos propostos para a avaliação de danos são: o modelo do ponto crítico, o modelo de múltiplos pontos, o modelo integral, o modelo de superfície de resposta e modelos envolvendo a estimativa de tecido sadio remanescente (James, 1974; Main, 1978; Teng ${ }^{3}$, citado por Bergamin Filho \& Amorim, 1991; Waggoner \& Berger, 1987, Bergamin Filho, 1995; Bergamin Filho et al., 1995; Bergamin Filho \& Amorim, 1996). Para cada método e para cada patossistema são estabelecidas funções matemáticas, onde a produtividade é uma variável dependente do tecido foliar doente ou do tecido sadio remanescente. De modo geral, as melhores funções (estabelecidas por análises de regressão) são obtidas quando se realizam várias avaliações de intensidade da doença durante o ciclo da cultura (Teng ${ }^{3}$, citado por Bergamin Filho \& Amorim, 1991). Deste modo, a partir do monitoramento da doença no campo, pode-se prever possíveis danos e perdas. A importância prática desses modelos reside, não apenas na estimativa das perdas mas, principalmente, no manejo das medidas de controle.

No modelo de ponto crítico, os danos são relacionados com a intensidade da doença avaliada num determinado estádio da cultura. Um bom exemplo do emprego desse modelo encontra-se no trabalho de Ayers et al. (1976). Os autores verificaram que a produção do milho foi função dos danos causados por Helminthosporium maydis raça $T$, segundo a equação $P=9,3-0,04 X$, onde $P$ é a produção em toneladas por hectare e $\mathrm{X}$ é a severidade da doença avaliada aos 73 dias da cultura.

No modelo de múltiplos pontos, os danos são estimados em função da intensidade da doença em vários estádios de desenvolvimento da cultura. Burleigh et al. (1972), determinaram os danos causados por Puccinia recondita f. sp. tritici em trigo através desse modelo. A equação encontrada pelos autores foi $\mathrm{Y}=5,37+5,52 \mathrm{X}_{2}-$ $0,33 \mathrm{X}_{5}+0,50 \mathrm{X}_{7}$, onde $\mathrm{Y}$ é o dano, em percentagem, $\mathrm{X}_{2}$ é a severidade por perfilho no estádio 10 da escala de Feekes, $\mathrm{X}_{5}$ é a severidade na folha bandeira no estádio $11,1 \mathrm{e} \mathrm{X}_{7}$, a severidade na folha bandeira no estádio 11,2 .

\footnotetext{
${ }^{3}$ TENG, P.S. Use of regression analysis for developing crop loss models. In: FAO. Crop loss assessment methods. Famham Royal: Commonwealth Agricuitural Bureaux, 1981. p.51-55. Supplement, 3.
} 
O modelo integral relaciona os danos com alguma variável que representa a totalidade da epidemia, como por exemplo a área abaixo da curva de progresso da doença (AACPD). Diversos autores já utilizaram, com sucesso, a AACPD em modelos de previsão de danos. Schneider et al. (1976) encontraram a função Y=0,43 AACPD $14,95\left(\mathrm{R}^{2}=0,70\right)$ para estimar os danos causados pela cercosporiose do caupi. Para o patossistema alfafa - Phoma medicaginis e Stemphylium botryosum, a função de danos encontrada foi $\mathrm{Y}=-0,22+0,142$ AACPD $\left(\mathrm{R}^{2}=0,52\right)$ (Broscious et al., 1987). Mais recentemente, Bisht \& Agrawal (1994), estudando os efeitos da mancha púrpura na produção do alho, durante dois anos consecutivos, estabeleceram as funções $Y=-0,35+$ 0,09 AACPD $\left(\mathrm{R}^{2}=0,85\right)$ e $\mathrm{Y}=1,91+0,08$ AACPD $\left(\mathrm{R}^{2}=0,87\right)$, para o primeiro e segundo ano, respectivamente.

Modelos que utilizam dois tipos de variáveis independentes na estimativa de danos são considerados modelos de superficie de resposta. Nesses modelos, os danos (variável dependente) são estudados, geralmente, em função da intensidade de doença e do estádio de desenvolvimento do hospedeiro (variáveis independentes). Um exemplo clássico da utilização desse modelo pode ser encontrado no trabalho de Kirby \& Archer (1927), com o patossistema trigo - Puccinia graminis f. sp. tritici.

Nos últimos anos, observa-se uma tendência crescente de utilização dos modelos que envolvem a estimativa de tecido sadio remanescente (ou suas variantes). Esses modelos baseiam-se na hipótese de que, para alguns patossistemas, a produção de uma determinada cultura é determinada pelo tecido que permanece sadio, e não pelo tecido doente (Waggoner \& Berger, 1987). Nessa linha, Carneiro et al. (1997) demonstraram que alguns componentes da produção de plantas de feijoeiro não apresentaram boa correlação com a AACPD, no caso de epidemias de mancha angular. Por outro lado, quando se utilizaram as variáveis duração da área foliar sadia (HAD) e absorção da área foliar sadia (HAA) (calculadas à partir do tecido sadio remanescente), obteve-se bons ajustes $\left(\mathrm{R}^{2} \cong 0,65\right)$ entre estas variáveis e os componentes da produção. Da mesma forma, Bergamin Filho et al. (1997), também estudando o patossistema feijoeiro - Phaeoisariopsis griseola, encontraram boas correlações entre a produção e as variáveis HAD, HAA e radiação interceptada pela área foliar sadia (HRI). Mais uma vez, a AACPD não foi um bom parâmetro para explicar os danos. 
Existem poucos exemplos do emprego desses modelos para as fitoviroses em geral. Isso pode ser explicado pelo fato de que os levantamentos de fitoviroses estão, muitas vezes, associados a levantamento de insetos vetores, o que é desencorajador ao fitopatologista (Madden \& Campbell, 1986). No entanto, com o crescente avanço da epidemiologia, a tendência que se observa é de utilização ampla desses modelos para qualquer tipo de doença de plantas (Bergamin Filho \& Amorim, 1991).

Dados sobre danos causados pelos enfezamentos vermelho e pálido são raros no Brasil, provavelmente devido à pouca importância que estas doenças apresentavam até que fossem mudadas as condições tradicionais de cultivo. Alguns relatos de "sérios prejuizos" (Kitajima \& Nazareno, 1985), "produção reduzida" e "produção nula" (Oliveira et al., 1998) podem ser encontrados em trabalhos sobre os enfezamentos. Porém, não existem estudos detalhados sobre determinação de danos causados por essas doenças nas nossas condições. Em alguns outros países, no entanto, os danos estão melhor caracterizados. Nos Estados Unidos, Scott et al. (1977) estimaram, durante três anos, os efeitos dos enfezamentos sobre a produção de híbridos de milho e obtiveram uma reta de regressão entre a produção e a época de aparecimento de sintomas. A produção foi nula sempre que o aparecimento dos sintomas precedeu ao dia 52, a contar da semeadura. Após o dia 52, para cada dia de atraso na expressão dos sintomas, foi constatado um ganho de $1,82 \%$ na produção e, após o dia 107 , a manifestação de sintomas mostrou não ter efeito na produção. Num outro estudo, realizado na Nicarágua por Hruska \& Peralta (1997), plantas de milho expostas à infecção natural dos agentes dos enfezamentos nos intervalos de 0-10,10-20, e 20-30 dias após a emergência, os danos foram de 37,21 e $28 \%$, respectivamente. Porém, quando a exposição foi realizada entre os dias 30 e 40, a redução na produção foi de apenas $7 \%$. 


\section{QUANTIFICAÇÃO DE DANOS CAUSAdOS PELO ENFEZAMENTO VERMELHO E ENFEZAMENTO PÁLIDO DO MILHO EM CONDIÇÕES DE CAMPO}

\subsection{RESUMO}

Os danos provocados pelos enfezamentos vermelho e pálido do milho foram quantificados em 15 ensaios de campo, durante os anos agrícolas de 95/96 e 96/97, em Piracicaba-SP, Jardinópolis-SP e Jacarezinho-PR. Foram utilizados os híbridos suscetiveis Dina-933e e XL-510, semeados em parcelas com 4 linhas de 5 metros cada. Metade das parcelas foi mantida sadia (parcelas controle) por meio de pulverizações semanais de inseticidas para controle do vetor (Dalbulus maidis). A outra metade ficou exposta à infecção natural. Foram feitas avaliações semanais dos sintomas, até o estádio de grãos pastosos. As características das curvas de progresso da doença não permitiram ajustá-las a nenhum modelo de crescimento populacional, usado em análises epidemiológicas. A incidência da doença no estádio de grãos pastosos correlacionou-se bem com os danos para ambos os híbridos. Funções de danos ajustadas para este estádio indicaram dano de $0,8 \%$ na produção para cada $1 \%$ de aumento na incidência, para os 2 híbridos estudados. Esta mesma variação na incidência provocou reduções no peso de 1000 grãos de $0,8 \%$ e $0,4 \%$ para os híbridos Dina-933e e XL-510, respectivamente. A área abaixo da curva de progresso da doença (AACPD) também apresentou relação com os danos. A doença influenciou negativamente o tamanho dos grãos somente para o híbrido Dina-933e. Quanto mais precoce foi a manifestação dos sintomas, maiores foram os danos para ambos os híbridos. Não foi observado efeito de compensação entre plantas doentes e sadias, nem correlação entre incidência de enfezamento e população de $D$. maidis. Os resultados indicaram que a utilização de híbridos suscetíveis pode trazer sérios prejuízos aos agricultores. 


\subsection{INTRODUÇÃO}

O enfezamento vermelho e o pálido são doenças que ocorrem na cultura do milho no sul dos Estados Unidos e em diversos países da América Latina, inclusive no Brasil (Costa et al., 1971; Oliveira et al., 1998). Epidemias severas dessas doenças já foram relatadas nesses países, causando prejuízos aos agricultores (Bradfute et al., 1981; Nault et al., 1981; Hruska et al., 1996; Oliveira et al., 1998). Os primeiros relatos datam da década de 40 (Altstatt, 1945), porém, somente por volta de 1970 foi descoberta a identidade dos agentes causais (Granados, 1969; Davis et al., 1972).

Um espiroplasma (Spiroplasma kunkelii) é o agente causal do enfezamento pálido, doença que corresponde ao "Corn Stunt" (CS), e um fitoplasma está associado ao enfezamento vermelho. Recentemente foi constatado, por meio de PCR e RFLP, que o fitoplasma que ocorre no Brasil é geneticamente similar ao agente da doença conhecida como "Maize Bushy Stunt" (MBS) que ocorre nos Estados Unidos (Bedendo et al., 1997). Ambos os patógenos são transmitidos pela cigarrinha do milho Dalbulus maidis DeLong \& Wolcott, de maneira persistente propagativa (Nault, 1980) e podem ocorrer em infecções conjuntas ou isoladas.

A literatura registra diferenças na sintomatologia para plantas infectadas com espiroplasma (enfezamento pálido) e fitoplasma (enfezamento vermelho). Plantas com enfezamento pálido exibem estrias cloróticas paralelas às nervuras, localizadas principalmente próximas à base das folhas. Por outro lado, sintomas de avermelhamento dos bordos ou de toda a folha e de perfilhamento da planta são atribuídos ao fitoplasma. Alguns outros sintomas, como redução no porte da planta e proliferação de espigas são atribuídos a ambos os patógenos indistintamente (Shurtleff, 1986). Entretanto, Nault (1980) demonstrou que o quadro sintomatológico das plantas afetadas pelos dois tipos de enfezamentos, além dos agentes causais, sofre influência do genótipo do hospedeiro e de alguns fatores do ambiente.

Nos Estados Unidos, Scott et al. (1977) verificaram danos médios de 50\% devido aos enfezamentos do milho, porém, mais alarmante foi a constatação de que plantas infectadas precocemente tiveram sua produção reduzida a zero. No Brasil, não haviam dados sobre os danos causados pelos enfezamentos, provavelmente devido à 
pequena importância que essas doenças apresentavam até que fossem mudadas as condições tradicionais de cultivo. Atualmente, a expansão dos plantios "safrinha" e a adoção de irrigação proporcionam, em alguns locais, a presença de milho no campo durante $\mathrm{o}$ ano inteiro. Isso acarretou mudanças no comportamento de alguns patossistemas, principalmente naqueles envolvendo insetos vetores (Oliveira et al., 1997).

Estimativas confiáveis dos prejuízos causados por patógenos são necessárias para o desenvolvimento de qualquer programa bem sucedido de controle de doenças, além de servirem como base para orientação de pesquisas e decisões governamentais. É necessário que se conheça o valor do prejuizo, para que, em conjunção com o custo do controle, uma decisão racional possa ser tomada (Bergamin Filho, 1995; Campbell \& Madden, 1990).

Este capítulo teve por objetivo quantificar os danos causados pelos dois tipos de enfezamento do milho em condições de campo. Além disso, buscou determinar uma relação entre agentes causais e sintomatologia e entre incidência das doenças e população do inseto vetor. 


\subsection{MATERIAL E MÉTODOS}

\subsubsection{Instalação dos ensaios}

No período compreendido entre novembro/95 e março/97 foram instalados 15 ensaios de campo em diferentes localidades (Tabela 1). Foram utilizados os híbridos suscetiveis de milho XL-510 e Dina-933e.

Tabela 1. Ensaios realizados com os híbridos de milho Dina-933e e XL-510 para avaliação de danos devido aos enfezamentos vermelho e pálido.

\begin{tabular}{ccccc}
\hline $\mathrm{N}^{0}$ do ensaio & Local & Híbrido & Safra & Data do plantio \\
\hline 01 & Piracicaba-SP & Dina-933e & $95 / 96$ & $23 / 11 / 95$ \\
02 & Piracicaba-SP & Dina-933e & $95 / 96$ & $21 / 12 / 95$ \\
03 & Piracicaba-SP & Dina-933e & $95 / 96$ & $29 / 03 / 96$ \\
04 & Jacarezinho-PR & Dina-933e & $95 / 96$ & $11 / 03 / 96$ \\
05 & Jardinópolis-SP & Dina-933e & $96 / 97$ & $23 / 12 / 96$ \\
06 & Jacarezinho-PR & XL-510 & $96 / 97$ & $13 / 12 / 96$ \\
07 & Jacarezinho-PR & XL-510 & $96 / 97$ & $10 / 03 / 97$ \\
08 & Piracicaba-SP & Dina-933e & $96 / 97$ & $27 / 11 / 96$ \\
09 & Piracicaba-SP & Dina-933e & $96 / 97$ & $20 / 12 / 96$ \\
10 & Piracicaba-SP & Dina-933e & $96 / 97$ & $31 / 01 / 97$ \\
11 & Piracicaba-SP & Dina-933e & $96 / 97$ & $13 / 03 / 97$ \\
12 & Piracicaba-SP & XL-510 & $96 / 97$ & $18 / 10 / 96$ \\
13 & Piracicaba-SP & XL-510 & $96 / 97$ & $10 / 12 / 96$ \\
14 & Piracicaba-SP & XL-510 & $96 / 97$ & $14 / 02 / 97$ \\
15 & Piracicaba-SP & XL-510 & $96 / 97$ & $12 / 03 / 97$ \\
\hline
\end{tabular}

Todos os ensaios foram instalados com espaçamento de $0,8 \mathrm{~m}$ entre linhas e densidade de 4 plantas $/ m$. As adubações de plantio e cobertura foram realizadas de 
acordo com análises de solo e recomendações para a cultura do milho. As parcelas foram constituídas por 4 linhas com $5 \mathrm{~m}$ de comprimento, com uma linha de plantio separando uma parcela da outra. $\mathrm{O}$ número de parcelas variou de 8 a 16 entre os ensaios. $\mathrm{O}$ delineamento estatístico adotado foi o completamente casualizado. Metade das parcelas ficou exposta à infestação natural da cigarrinha vetora $D$. maidis (parcelas doentes) e a outra metade recebeu tratamentos com inseticidas para evitar a ocorrência de enfezamento (parcelas controle). Esses tratamentos incluíram a aplicação de carbofuran no sulco de plantio e de uma mistura de Monocrotophos e Lambdacyalothrin em pulverizações semanais, que se estenderam até por volta da $7^{\mathrm{a}}$ semana após a semeadura. Além disso, em cada plantio foram realizadas 2 aplicações do inseticida fisiológico Diflubenzuron na área toda, incluindo as parcelas não tratadas, para o controle da lagarta do cartucho (Spodoptera frugiperda J.E. Smith). Este inseticida tem controlado eficientemente lepidópteros, porém não tem interferido na população de $D$. maidis.

\subsubsection{Avaliação das doenças e das populações de $D$. maidis}

Nos ensaios de números 8 a 15, as avaliações foram feitas semanalmente, sendo iniciadas por volta da $4^{\mathrm{a}}$ ou $5^{\mathrm{a}}$ semana após a emergência e estendendo-se até o estádio de grãos pastosos (estádio 7, segundo Fancelli \& Lima, 1992). Em cada avaliação, foi anotada a incidência de plantas com ambos os tipos de enfezamentos em cada uma das parcelas. Nos demais ensaios foi realizada apenas uma avaliação no estádio de grãos pastosos, visando determinar a incidência final dos enfezamentos. Durante as avaliações, foram consideradas doentes as plantas que apresentaram sintomas de avermelhamento, amarelecimento ou estrias cloróticas nas folhas, combinados ou não com redução no porte da planta e proliferação de espigas (Nault, 1980; Shurtleff, 1986; Oliveira et al., 1998). Para os ensaios onde foram realizadas avaliações semanais, foi calculada a área

abaixo da curva de progresso da doença (AACPD) para cada parcela, pelo método da integração trapezoidal (Berger, 1988). Após a última avaliação de cada ensaio, foram coletadas amostras foliares de algumas plantas sintomáticas para a realização de testes visando a deteç̧ão dos agentes causais. Essas amostras foram mantidas em ultra-freezer 
$\left(-80^{\circ} \mathrm{C}\right)$ até o momento dos testes. Os testes realizados visaram à detecção de espiroplasma e fitoplasma, respectivamente, por meio de PTA-ELISA ("plate-trapped antigen enzyme-linked immunosorbent assay") (Mowat \& Dawson, 1987), com antisoro policlonal para S. kunkelii, e PCR ("polymerase chain reaction"), com os "primers" R16F2 e R16R2 (Lee et al., 1993). Foram consideradas positivas no teste PTA-ELISA as amostras que apresentaram valores de absorbância no mínimo duas vezes maior que o apresentado pelo controle sadio (Sutula et al., 1986). As reações foram avaliadas por meio de um leitor de ELISA S960 (Metertech, Taiwan) a 405 ๆm. No teste de PCR, foi seguida a metodologia descrita por Lee et al. (1993), sendo consideradas positivas as amostras que apresentaram bandas de $1,2 \mathrm{~Kb}$ em gel de agarose.

As populações de D. maidis foram monitoradas por meio de armadilhas transparentes adesivas instaladas no meio das parcelas. Utilizou-se armadilhas em 3 a 4 parcelas doentes de cada ensaio. As armadilhas foram trocadas semanalmente, desde as primeiras semanas até por volta do florescimento. Em cada armadilha foi contado o número de adultos de $D$. maidis capturados.

\subsubsection{Avaliação da produção e dos danos}

Para avaliação da produção, foram colhidas as duas linhas centrais de cada parcela. Após a colheita, determinou-se a umidade dos grãos por meio de secagem em estufa a $105 \pm 2{ }^{\circ} \mathrm{C}$ por 24 horas. As produções de cada parcela foram corrigidas para $12 \%$ de umidade dos grãos. As variáveis avaliadas foram produção das parcelas (g/parcela), peso de 1000 grãos e porcentagem de grãos em diferentes tamanhos. Para avaliação do peso de 1000 grãos, foram retiradas, aleatoriamente, 4 amostras de 100 grãos de cada parcela, as quais foram pesadas e transformadas para o peso de 1000 grãos. Em seguida,

foram calculados os danos na produção de grãos e no peso de 1000 grãos para cada ensaio, por meio de comparações entre as parcelas doentes com as respectivas parcelas controle. Para a avaliação da porcentagem de grãos de diferentes tamanhos, amostras de $200 \mathrm{~g}$ de grãos de cada parcela foram separadas por um conjunto de peneiras com malhas circulares de tamanhos decrescentes $(9,52 ; 8,73 ; 7,93$ e 7,14 mm). Em seguida, foi obtido 
o peso dos grãos que ficaram retidos em cada peneira e aqueles que passaram pela peneira de $7,14 \mathrm{~mm}$. Com esses resultados, foi calculada a variação na quantidade de grãos retidos em cada peneira, em relação às parcelas controle, através da fórmula:

Variação $=\frac{\% \text { de grãos das parcelas doentes retidos em cada peneira }}{\% \text { de grãos das parcelas controle retidos em cada peneira }}$

\subsubsection{Efeito da época de manifestação de sintomas sobre os danos}

Nos ensaios de números 11 e 15, as novas plantas sintomáticas encontradas em cada avaliação foram marcadas com fitas coloridas (uma cor para cada avaliação) e colhidas separadamente, com a finalidade de verificar a relação entre época de manifestação de sintomas e produção de grãos. Os danos para essas plantas foram calculados tomando-se como base a produção média das plantas das parcelas sadias.

\subsubsection{Efeito de compensação entre plantas doentes e sadias}

Nos ensaios de números 10, 11, 14 e 15, foram marcadas plantas para determinar um possível efeito de compensação, segundo metodologia descrita por Dias et al. (1984). Nesses ensaios foram identificadas as seguintes seqüências de plantas: sadiasadia-sadia (SSS), doente-sadia-doente (DSD) e sadia-sadia-doente (SSD). Para os ensaios 10 e 11, foram marcadas, em cada um deles, 20 seqüências SSS e 15 seqüências SSD. Nesses ensaios, não foram marcadas seqüências DSD devido à baixa freqüência com que apareceram. Nos ensaios 14 e 15, foram marcadas, respectivamente, 20 e 20 seqüências SSS, 16 e 15 seqüências SSD e 9 e 10 seqüências DSD. As plantas centrais de cada uma dessas seqüências foram colhidas separadamente para avaliação da produção. 


\subsubsection{Análises dos resultados}

As análises estatísticas foram realizadas por meio dos programas SAS para Windows (SAS Institute, Cary, NC) e PlotIT para Windows (Scientific Programming Enterprises, Haslett, MI). As funções de dano foram obtidas por regressão linear entre os dados de incidência (variável independente), expressos em porcentagem de plantas doentes ou em área abaixo da curva de progresso do número de plantas doentes, e dano (variável dependente), expresso em porcentagem de redução na produção em função das parcelas sadias. As funções de dano foram calculadas para dados de incidência nos estádios fenológicos 3 a 7. A comparação entre as funções de danos para ambos os híbridos foi realizada por meio do teste $t$ aplicado aos parâmetros (constante e coeficiente angular) das retas. Os valores de variação nas porcentagens de grãos retidos em cada peneira foram submetidos à análises de correlação com as respectivas incidências no estádio fenológico 7. Regressões não-lineares com o modelo $\mathrm{Y}=\mathrm{A}+\mathrm{BX}+\mathrm{CX} \mathrm{C}^{2}$ foram aplicadas para relacionar danos com época de aparecimento de sintomas. A comparação entre as produções das plantas centrais das seqüências sadia-sadia-sadia (SSS), sadiasadia-doente (SSD) e doente-sadia-doente (DSD) foi feita pelo teste de Tukey. Para todos os ensaios, foram correlacionadas as populações do vetor, avaliadas semanalmente, com a incidência dos enfezamentos no estádio fenológico 7. Além disso, para os ensaios onde a doença foi avaliada semanalmente $\left(5^{\mathrm{a}}\right.$ a $11^{\mathrm{a}}$ semanas após a emergência), foram realizados testes de correlação entre as incidências observadas e as populações de cigarrinhas registradas entre a $2^{\mathrm{a}}$ e $7^{\mathrm{a}}$ semanas após a emergência das plantas. 


\subsection{RESULTADOS E DISCUSSÃO}

\subsubsection{Diagnose dos agentes dos enfezamentos vermelho e pálido}

Um total de 145 amostras foliares de plantas com diversos sintomas de ambos os enfezamentos foram coletadas durante os ensaios e testadas por meio de PTA-ELISA para deteç̧ão de $S$. kunkelii. Destas, 43 amostras foram positivas. Entre as amostras positivas, 15 apresentavam sintomas de avermelhamento, 6 apresentavam amarelecimento e 22 apresentavam ambos os sintomas. O número de amostras com sintomas de estrias cloróticas nas folhas foi baixo (apenas 5 dentre as 145 testadas), porém todas elas foram positivas para S. kunkelii. Ainda, das 19 amostras que apresentavam sintomas de proliferação excessiva de espigas, 14 mostraram resultado positivo para S. kunkelii. Das 145 amostras coletadas em campo, 32 foram escolhidas ao acaso e submetidas ao teste de PCR para deteç̧ão de fitoplasma. Destas, 9 apresentaram banda de 1,2 Kb, indicativa da presença de fitoplasma. Entre essas amostras positivas, 2 apresentavam sintomas de avermelhamento, apenas 1 apresentava amarelecimento e 6 apresentavam ambos os sintomas. Entre as 32 amostras testadas por PCR, 3 delas apresentavam sintomas de estrias cloróticas nas folhas e em nenhuma delas foi detectado fitoplasma. Das 8 amostras que mostravam sintomas de proliferação de espigas, 4 apresentaram o fitoplasma. Os resultados do teste PTA-ELISA e PCR revelaram índices relativamente baixos de deteç̧ão de $S$. kunkelii e fitoplasma nas plantas com sintomas de ambos os enfezamentos. Resultados semelhantes a estes já foram relatados por outros pesquisadores (Oliveira et al., 1998). A explicação para essa baixa deteç̧ão pode ser a distribuição irregular destes microrganismos nas plantas infectadas (Davis, 1995b). Entretanto, esses resultados permitem que sejam feitas algumas observações: (i) os sintomas de estrias cloróticas são realmente indicativos de infecção por S. kunkelii, como já foi relatado anteriormente (Nault, 1980; Shurtleff, 1986; Oliveira et al., 1998); (ii) os sintomas de avermelhamento das folhas não devem ser considerados como resultado da infecção por fitoplasma somente, uma vez que foi detectada a presença exclusiva de $S$. kunkelii em diversas amostras com esses sintomas, constatando o que já havia sido relatado por Bajet \& Renfro (1989); (iii) os sintomas de amarelecimento e proliferação 
excessiva de espigas parecem estar associados a ambos os patógenos indistintamente. Entretanto, apesar dessas observações, a sintomatologia dos dois tipos de enfezamentos do milho não deve ser considerada como função dos agentes causais somente, corroborando os resultados de Nault (1980).

\subsubsection{Curvas de progresso das doenças}

Para os ensaios de números 8 a 15 , devido à avaliação semanal realizada, foi possível construir as curvas de progresso da doença no tempo (Figura 1). Na maioria delas, a incidência da doença aumentou consideravelmente à partir de 50 a 60 dias após a emergência, ou seja, após o florescimento do milho, provavelmente devido ao longo período de incubação das doenças. Plantas infectadas durante a fase vegetativa mostram os sintomas apenas após o florescimento. Em razão da expressão tardia dos sintomas dos enfezamentos, os trabalhos de avaliação dessa doença em campo sempre consideram as incidências em estádios mais avançados da cultura (Folegatti et al., 1997; Hruska \& Peralta, 1997; Lezcano \& Machado, 1997; Oliveira et al., 1998). 


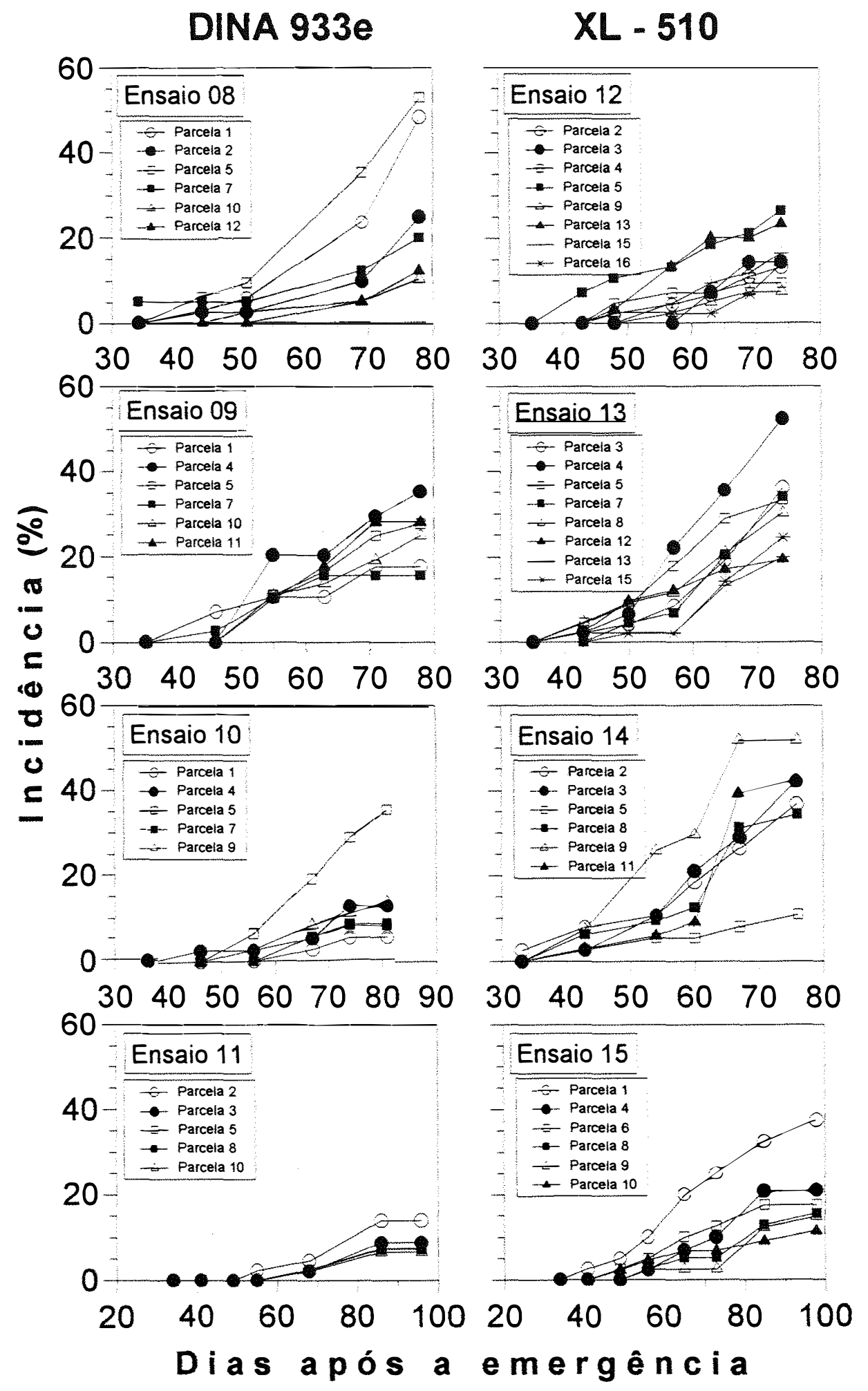

Figura 1. Curvas de progresso dos enfezamentos vermelho e pálido do milho para os híbridos Dina 933e e XL-510, para os ensaios realizados na safra 96/97 em Piracicaba. 
Algumas outras características podem ser notadas nas curvas representadas na Figura 1: (i) as incidências finais foram muito variáveis entre as parcelas de um mesmo ensaio (ensaios 08, 10, 1314 e 15); (ii) houveram casos em que se atingiu incidências altas e não houve estabilização da curva (assíntota), com a epidemia em pleno crescimento no final do ciclo do milho (ensaios 08 e 13), por outro lado, em alguns ensaios houve estabilização das curvas em incidências baixas (ensaios 11 e 15); (iii) as curvas apresentaram formas muito variáveis, algumas delas semelhantes a alguns modelos propostos na literatura, outras, porém, não se ajustariam a tais modelos.

Essas características impedem que sejam feitas análises entre as variáveis das curvas (inóculo inicial e taxa aparente de infecção) e os danos. Este tipo de análise pode ser feito somente quando determinados pré-requisitos forem observados. As taxas só podem ser utilizadas em comparações, por exemplo, dentro de um mesmo modelo, ou seja, as diferentes epidemias devem se ajustar a um único modelo de crescimento. Além do problema relacionado à forma da curva, a quantidade máxima da doença ao final da epidemia (assintota) é outra variável que pode tornar as taxas de progresso de doença sem valor para comparações (Campbell \& Madden, 1990). Quando as incidências finais são muito variáveis, o procedimento de regressão não-linear com assíntota variável é indicado. Porém, nesse tipo de análise, grandes variações na quantidade máxima final de doença podem ser obtidos com um mesmo valor para a taxa aparente de infecção, tornando-a inútil para comparações (Park \& Lim, 1985). Quando a curva de progresso da doença apresenta formas que não se ajustam a nenhum modelo proposto, a área abaixo da curva de progresso da doença (AACPD) pode ser usada como parâmetro para descrever a epidemia (Shaner \& Finney, 1977). Segundo Vanderplank (1963), a AACPD constitui-se numa importante variável em estudos envolvendo danos, por agrupar, num único valor, a intensidade e o período de duração da doença. 


\subsubsection{Relação entre danos e incidências}

Para os ensaios ilustrados na Figura 1, foram efetuadas regressões lineares entre os danos e as respectivas incidências em diferentes estádios fenológicos da cultura do milho, encontrando-se as funções de danos (Tabela 2).

Tabela 2. Funções de danos na produção para os enfezamentos vermelho e pálido em diferentes estádios fenológicos do milho.

\begin{tabular}{lll}
\hline Estádio em que & \multicolumn{2}{c}{ Funções de danos** } \\
foi avaliada a & Híbrido Dina 933e & Híbrido XI-510 \\
incidência* & &
\end{tabular}

Estádio 3

$$
\mathrm{Y}=13,60+1,56 \mathrm{X}\left(\mathrm{R}^{2}=0,02\right)
$$$$
\mathrm{Y}=16,65+2,83 \mathrm{X}\left(\mathrm{R}^{2}=0,36\right)
$$

Estádio 4$$
\mathrm{Y}=14,90+1,40 \mathrm{X}\left(\mathrm{R}^{2}=0,37\right)
$$

Estádio 5

$$
\mathrm{Y}=11,91+1,43 \mathrm{X}\left(\mathrm{R}^{2}=0,09\right)
$$$$
\mathrm{Y}=12,44+1,08 \mathrm{X}\left(\mathrm{R}^{2}=0,44\right)
$$

Estádio 6

$$
\mathrm{Y}=9,28+0,82 \mathrm{X}\left(\mathrm{R}^{2}=0,16\right)
$$$$
\mathrm{Y}=7,54+0,74 \mathrm{X}\left(\mathrm{R}^{2}=0,55\right)
$$

Estádio 7

$$
\mathrm{Y}=0,46+0,82 \mathrm{X}\left(\mathrm{R}^{2}=0,64\right)
$$$$
\mathrm{Y}=3,90+0,76 \mathrm{X}\left(\mathrm{R}^{2}=0,66\right)
$$

* Estádios fenológicos da cultura do milho, segundo Fancelli \& Lima (1992)

** $\mathrm{Y}=$ dano $(\%) ; \mathrm{X}=$ incidência $(\%)$.

Pela Tabela 2, pode ser observado que, para ambos os híbridos, os danos na produção foram melhor relacionados com as incidências obtidas em estádios mais avançados. Os valores dos coeficientes de determinação $\left(R^{2}\right)$ mostraram que os melhores ajustes foram obtidos quando se considerou as incidências no estádio fenológico 7 . Em razão disso, foi estabelecida a relação entre os danos e as incidências nesse estádio, com os dados de todos os ensaios. As funções de danos na produção e no peso de 1000 grãos para ambos os híbridos testados foram significativas e com elevados valores para $\mathrm{R}^{2}$ (Figura 2). 


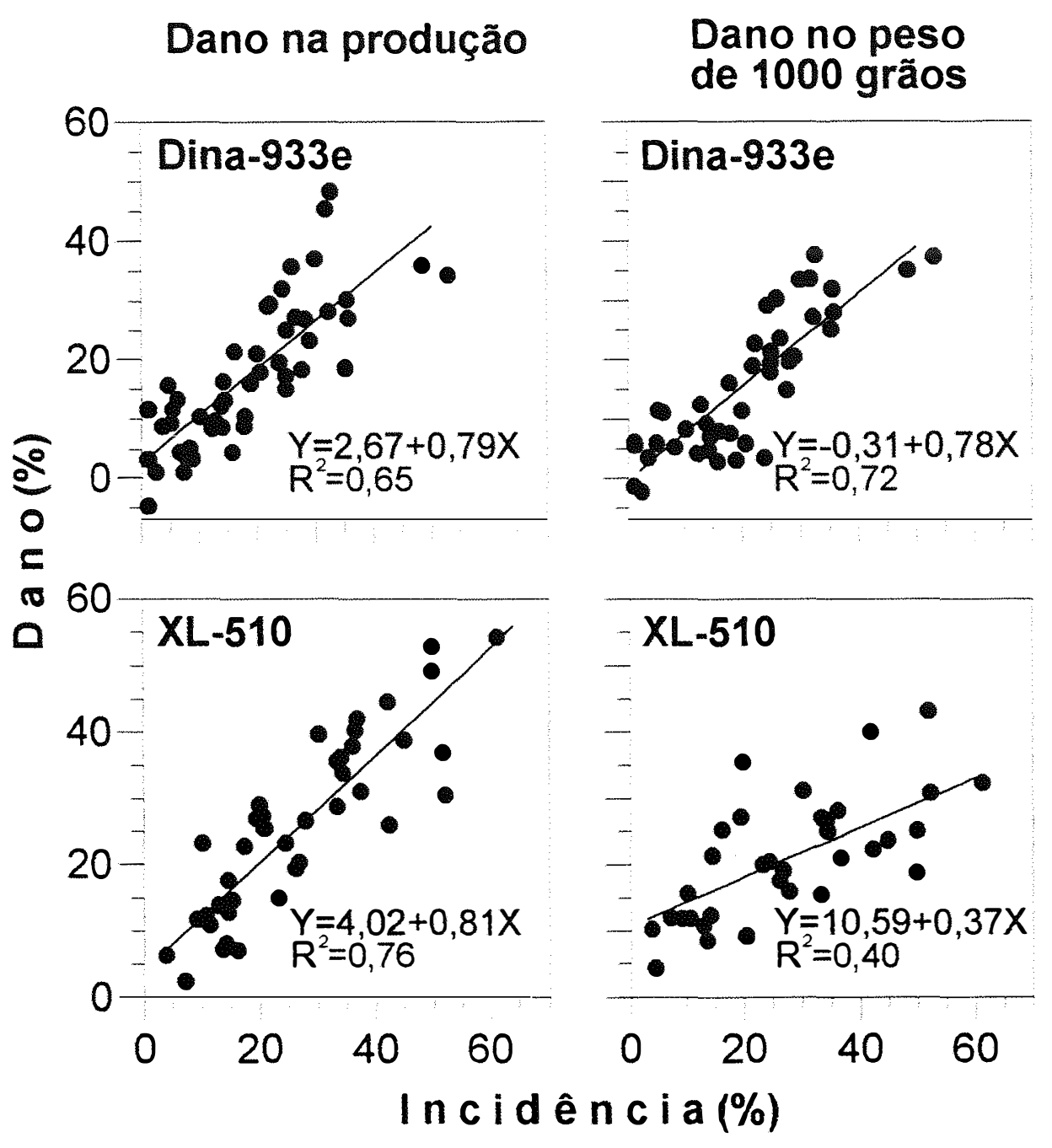

Figura 2. Danos na produção e no peso de 1000 grãos de milho em função da incidência dos enfezamentos vermelho e pálido no estádio fenológico 7, para os híbridos Dina-933e e XL-510 (Y = dano na produção (\%) e X = incidência (\%)).

Por meio do teste $t$, foi verificado que os parâmetros das retas que estimam os danos na produção não diferem entre ambos os híbridos. Isso indica que os híbridos Dina-933e e XL-510 comportaram-se da mesma forma em relação aos danos causados pelos enfezamentos. Dessa forma, uma nova regressão linear foi realizada com todos os dados e a nova função de danos encontrada, para os dois híbridos conjuntamente, foi $Y=$ $2,88+0,82 \mathrm{X}\left(\mathrm{R}^{2}=0,73\right)$, onde $\mathrm{Y}$ é o dano na produção (em porcentagem) e $\mathrm{X}$, a incidência dos enfezamentos. Essa equação mostra que, para cada $1 \%$ de aumento na incidência houve $0,8 \%$ de dano para ambos os híbridos. A mesma comparação entre 
retas, feita para as funções de danos no peso de 1000 grãos, indicaram que os híbridos se comportaram diferentemente em relação à essa variável. Assim, para variações de $1 \%$ na incidência ocorreram danos no peso de 1000 grãos de $0,8 \%$ para o híbrido Dina 933e e de $0,4 \%$ para o XL-510 (Figura 2). Estes resultados comprovaram que os enfezamentos do milho são doenças potencialmente destrutivas, podendo causar sérios prejuízos quando incidem sobre híbridos suscetiveis. Nas nossas condições, recentemente foram registrados prejuízos severos devido ao enfezamento do milho em lavouras irrigadas da região Centro-oeste (Oliveira et al., 1998). Esses autores alertaram que o uso de híbridos suscetíveis ao enfezamento pode acarretar perdas consideráveis aos agricultores.

\subsubsection{Relação entre danos e AACPD}

A AACPD também foi, assim como a incidência no estádio 7 , uma variável adequada para o ajuste das funções de danos causados pelos enfezamentos do milho (Figura 3). Outros autores já utilizaram com sucesso a AACPD em modelos de previsão de danos. Schneider et al. (1976) encontraram a função $Y=0,43$ AACPD $-14,95\left(R^{2}=\right.$ $0,70)$ para estimar os danos causados pela cercosporiose do caupi. Para o patossistema alfafa x Phoma medicaginis e Stemphylium botryosum, a função de danos encontrada foi $\mathrm{Y}=-0,22+0,142$ AACPD $\left(\mathrm{R}^{2}=0,52\right)$ (Broscious et al., 1987). Mais recentemente, Bisht \& Agrawal (1994), estudando os efeitos da mancha púrpura na produção do alho, durante dois anos consecutivos, estabeleceram as funções $Y=-0,35+0,09$ AACPD $\left(R^{2}=0,85\right)$ e $\mathrm{Y}=1,91+0,08$ AACPD $\left(\mathrm{R}^{2}=0,87\right)$, para o primeiro e segundo ano, respectivamente. Entretanto, apesar do bom ajuste encontrado entre AACPD e danos neste trabalho, recomenda-se, em estudos futuros, a utilização da incidência no estádio fenológico 7 para estimativas de danos, por ser esta variável mais facilmente obtida, uma vez que depende apenas de uma única avaliação em campo. A obtenção da AACPD requer avaliações periódicas da incidência e construção das curvas de progresso da epidemia, sendo, portanto, bem mais trabalhosa. 


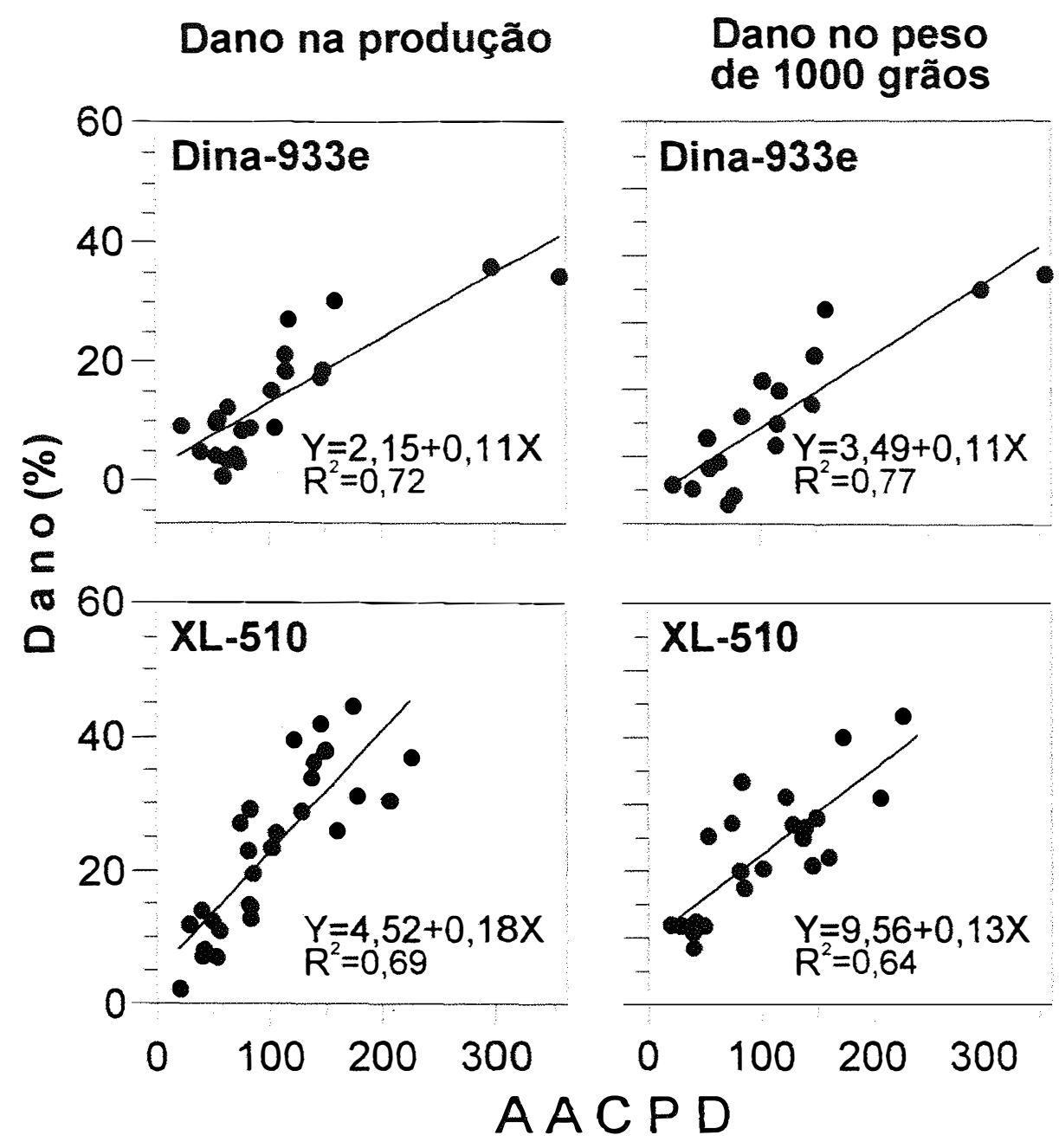

Figura 3. Danos na produção e no peso de 1000 grãos de milho em função da área abaixo da curva de progresso da epidemia dos enfezamentos vermelho e pálido (AACPD). Para o híbrido Dina-933e foram utilizados os ensaios 08 a 11 e para o híbrido XL-510 foram utilizados os ensaios 12 a 15 (Y=dano na produção $(\%)$ e $X=A A C P D)$. 


\subsubsection{Efeito da incidência dos enfezamentos vermelho e pálido sobre o tamanho dos grãos}

Os resultados das correlações entre incidências dos enfezamentos no estádio fenológico 7 e variações na porcentagem de grãos retidos em cada peneira são mostrados na Tabela 3 .

Tabela 3. Correlações entre variação nas porcentagens de grãos retidos em diferentes peneiras e as incidência dos enfezamentos vermelho e pálido no estádio fenológico 7, para os híbridos Dina-933e e XL-510.

\begin{tabular}{lll}
\hline Peneiras & \multicolumn{2}{c}{ Coeficientes de correlação(r)/Prob $>\mathrm{F}$} \\
\cline { 2 - 3 } & Híbrido Dina-933e & Híbrido XL-510 \\
\hline $9,52 \mathrm{~mm}$ & $\mathrm{r}=-0.73 / \mathrm{P}=0.0001$ & $\mathrm{r}=-0.08 / \mathrm{P}=0.6238$ \\
$8,73 \mathrm{~mm}$ & $\mathrm{r}=-0.61 / \mathrm{P}=0.0001$ & $\mathrm{r}=-0.18 / \mathrm{P}=0.2543$ \\
$7,93 \mathrm{~mm}$ & $\mathrm{r}=0.48 / \mathrm{P}=0.0004$ & $\mathrm{r}=-0.19 / \mathrm{P}=0.2415$ \\
$7,14 \mathrm{~mm}$ & $\mathrm{r}=0.61 / \mathrm{P}=0.0001$ & $\mathrm{r}=0.11 / \mathrm{P}=0.4828$ \\
$<7,14 \mathrm{~mm}$ & $\mathrm{r}=0.53 / \mathrm{P}=0.0001$ & \\
\hline
\end{tabular}

Observa-se que, para o híbrido Dina 933e, todas as correlações apresentaram valores significativos, indicando que a incidência de enfezamento apresentou influência no tamanho dos grãos desse híbrido. Entretanto, para o híbrido XL-510, isso não foi verificado. Como o peso de 1000 grãos desse híbrido foi afetado pela incidência de enfezamento (Figura 2), pode-se concluir que a doença causou o chocheamento dos grãos desse híbrido, porém sem alterar seu tamanho. A Figura 4 mostra que, para o híbrido Dina 933e, à medida que a incidência dos enfezamentos aumenta, há uma tendência de decréscimo na variação da porcentagem de grãos retidos pela peneira de $9,52 \mathrm{~mm}$ e acréscimo na variação da porcentagem de grãos retidos pela peneira de 7,14 mm, sendo este último mais claramente notado em incidências altas. Essa tendência não foi observada para o híbrido XL-510. 


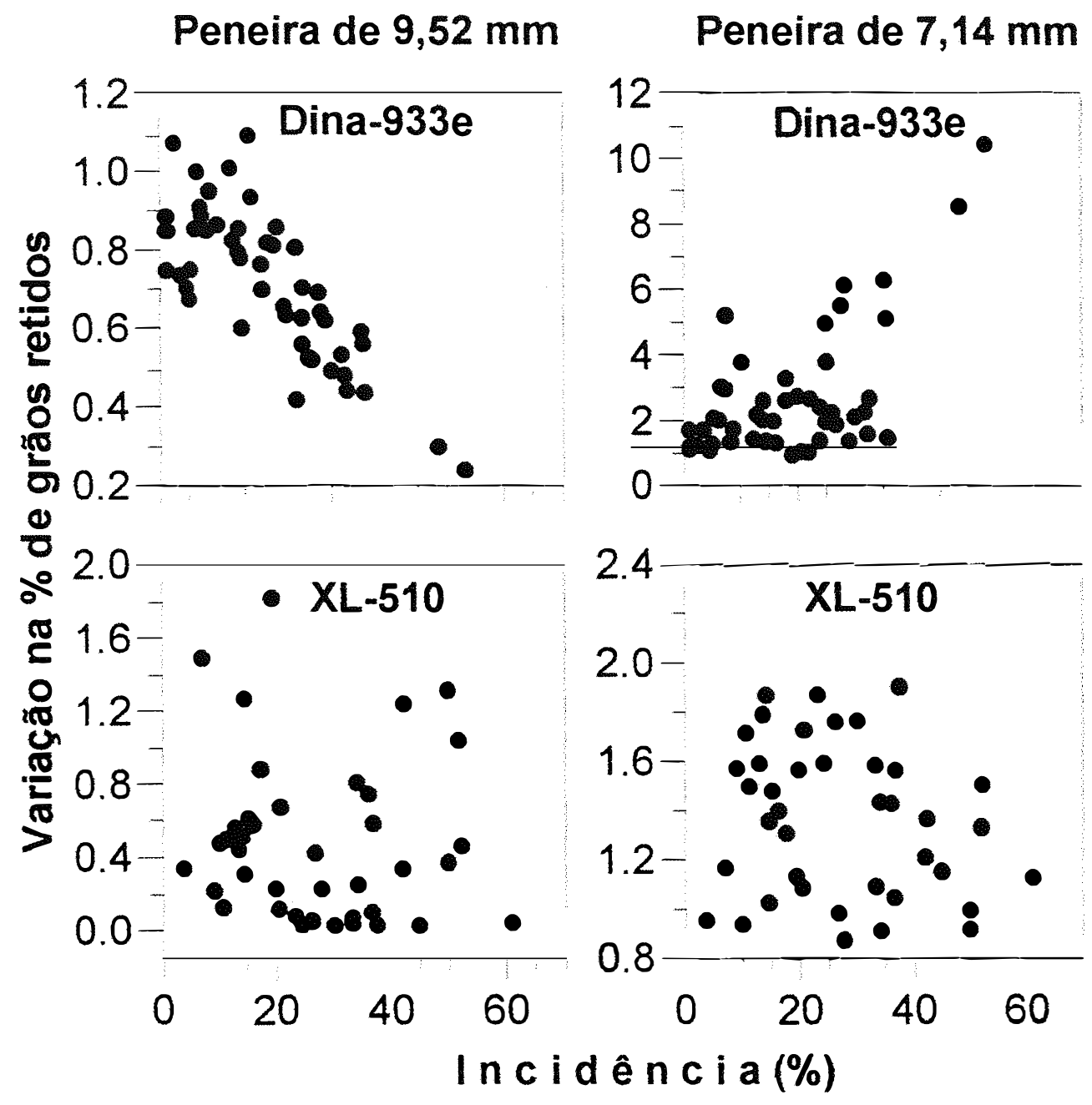

Figura 4. Variação nas porcentagens de grãos retidos nas peneiras de 9,52 e 7,14 mm para os híbridos de milho Dina-933e e XL-510, em função das incidências dos enfezamentos vermelho e pálido no estádio fenológico 7.

\subsubsection{Efeito da época de manifestação de sintomas sobre os danos}

A época do aparecimento dos sintomas no campo, a qual guarda uma correspondência com a época em que a planta foi infectada, mostrou ter influência marcante na produção para ambos os híbridos (Figura 5). O híbrido Dina 933e mostrou queda contínua nos danos à medida em que a expressão dos sintomas ocorreu mais 
tardiamente. Entretanto, para o híbrido XL-510, os danos foram decrescentes até por volta da $10^{\mathrm{a}}$ semana, quando mostraram uma estabilização, não sendo mais influenciados pela época de manifestação dos sintomas. Esses resultados foram muito semelhantes aos obtidos por Scott et al. (1977). Esses autores estimaram, durante três anos, os efeitos dos enfezamentos sobre a produção de híbridos de milho e obtiveram uma reta de regressão entre a produção e a época de aparecimento dos sintomas. A produção foi nula sempre que o aparecimento de sintomas precedeu ao dia 52, a contar da semeadura. Após o dia 52 , para cada dia de atraso, foi constatado um ganho de $1,82 \%$ na produção e, após o dia 107, a manifestação de sintomas mostrou não ter mais efeito na produção. Num outro estudo, realizado na Nicarágua por Hruska \& Peralta (1997), plantas de milho expostas à infecção natural dos agentes do enfezamento nos intervalos de 0-10, 10-20, e 20-30 dias após a emergência, os danos foram de 37,21 e $28 \%$, respectivamente. Porém, quando a exposição foi realizada entre os dias 30 e 40 , a redução na produção foi de apenas $7 \%$. 


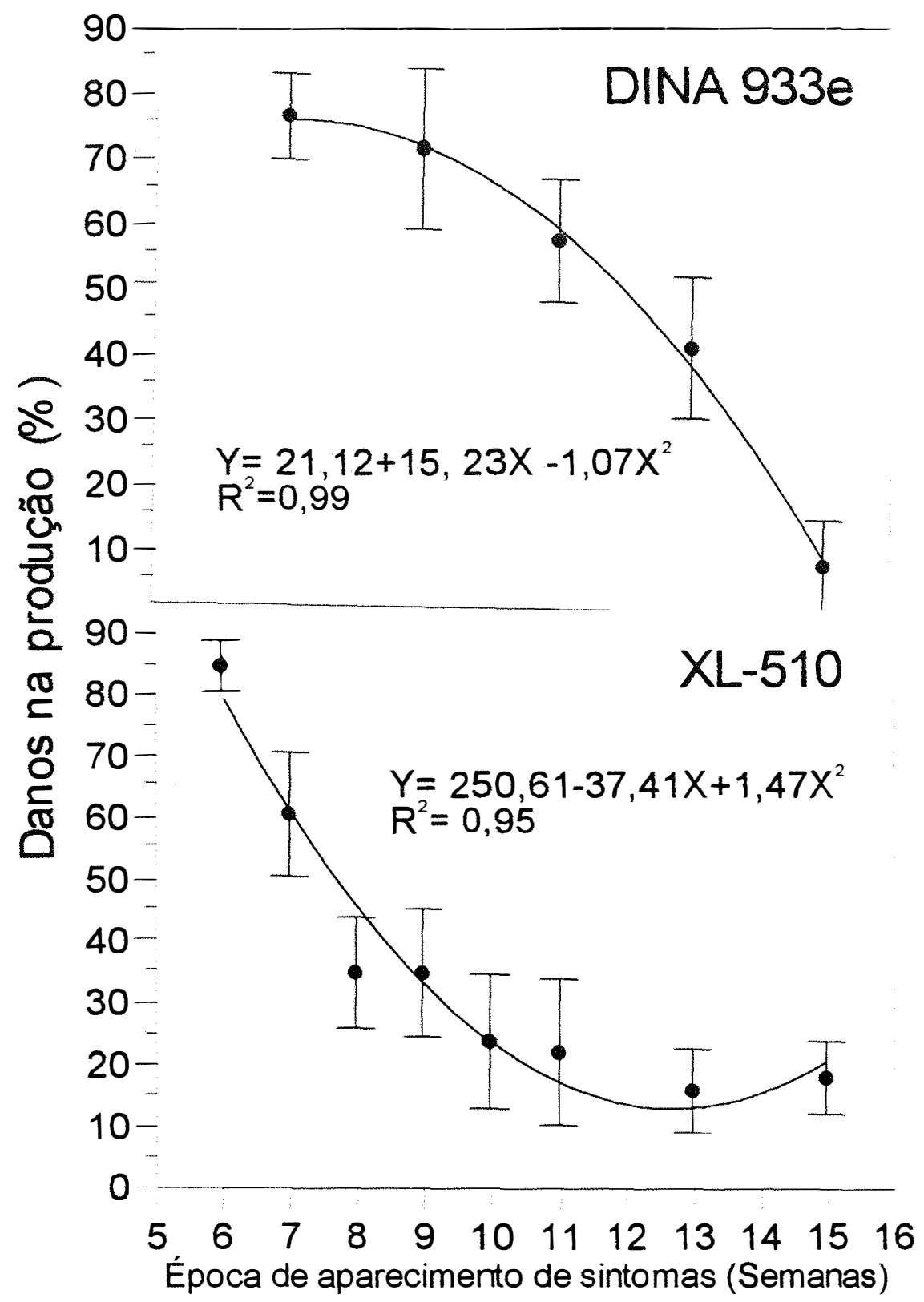

Figura 5. Danos na produção dos híbridos de milho Dina-933e e XL-510 em função da época de aparecimento dos sintomas dos enfezamentos vermelho e pálido no campo ( $\mathrm{Y}=$ dano na produção $(\%)$ e $\mathrm{X}=$ semana $)$. 


\subsubsection{Efeito de compensação entre plantas doentes e sadias}

O efeito de compensação, já identificado em outros patossistemas (Dias et al., 1984), deve-se ao fato de que plantas sadias, ao lado de plantas doentes, tendem a produzir mais, em função da menor competição. Isso pode mascarar os danos causados por doenças, principalmente em incidências baixas. No presente trabalho, o fenômeno de compensação entre plantas não foi detectado. As plantas centrais de cada uma das seqüências sadia-sadia-sadia (SSS), sadia-sadia-doente (SSD) e doente-sadia-doente (DSD) apresentaram produções semelhantes (Tabela 4).

Tabela 4. Produção média das plantas centrais das seqüências sadia-sadia-sadia (SSS), sadia-sadia-doente (SSD) e doente-sadia-doente (DSD) para os híbridos Dina 933 e e XL-510.

\begin{tabular}{|c|c|c|c|c|}
\hline \multirow{3}{*}{ Seqüência } & \multicolumn{4}{|c|}{ Produção (g/planta) } \\
\hline & \multicolumn{2}{|c|}{ Híbrido Dina 933e } & \multicolumn{2}{|c|}{ Híbrido XL-510 } \\
\hline & Ensaio 10 & Ensaio 11 & Ensaio 14 & Ensaio 15 \\
\hline S吕 & $93.44 \mathrm{a}$ & $101.41 \mathrm{a}$ & $171.45 \mathrm{a}$ & $142.29 \mathrm{a}$ \\
\hline S $\underline{S D}$ & $89.27 \mathrm{a}$ & $96.57 \mathrm{a}$ & $169.47 \mathrm{a}$ & $145.30 \mathrm{a}$ \\
\hline \multirow[t]{3}{*}{$\mathrm{D} \underline{S D}$} & $87.46 \mathrm{a}$ & $100.98 \mathrm{a}$ & N.D. & N.D. \\
\hline & C. $V .=28 \%$ & C.V. $=34 \%$ & C.V. $=25 \%$ & C.V. $=\mathbf{2 1 \%}$ \\
\hline & $\mathrm{DMS}=24.7 \mathrm{~g}$ & $\mathrm{DMS}=34,0 \mathrm{~g}$ & $\mathrm{DMS}=30.5 \mathrm{~g}$ & $\mathrm{DMS}=21.3 \mathrm{~g}$ \\
\hline
\end{tabular}

N.D. = não determinado

Médias seguidas de mesmas letras, nas colunas, não diferem entre si pelo teste de Tukey a 5\%.

A não ocorrência de compensação para estes patossistemas, provavelmente está relacionada com o longo periodo de incubação dessas doenças. A maioria das plantas doentes apresentaram os sintomas típicos quando já haviam atingido o porte final, após a fase de florescimento e, portanto, já haviam mobilizado os nutrientes do solo e ocupado seu respectivo espaço. Tais plantas, apesar da redução apresentada na produção, não permitiram que as plantas sadias vizinhas produzissem acima da média. Mesmo as plantas que apresentaram sintomas durante a fase vegetativa atingiram o porte normal, 
não sendo observada a redução de tamanho relatada na literatura para estas doenças (Nault, 1980; Shurtleff, 1980, Hruska \& Peralta, 1997).

\subsubsection{Populações de $D$. maidis e incidências dos enfezamentos vermelho e pálido}

Não houve correlação significativa entre as populações de cigarrinhas e incidências dos enfezamentos para nenhum dos híbridos (Tabelas 5 e 6). Apesar de existirem trabalhos indicando que os enfezamentos do milho são mais problemáticos em épocas do ano em que a população de D. maidis é maior no campo (Waquil et al., 1997), a não correlação observada neste trabalho já foi relatada por outros autores para este patossistema nas condições brasileiras (Folegatti et al., 1997) e também na Nicarágua (Hruska et. al., 1996). Provavelmente, isso esteja relacionado a uma variação na proporção de insetos infectivos dentro da população natural durante os ensaios mencionados. Estes resultados sugerem a necessidade da realização de estudos que revelem a flutuação sazonal na proporção de vetores infectivos. 
Tabela 5. Coeficientes de correlação (r) entre população de $D$. maidis e incidências dos enfezamentos vermelho e pálido em diferentes semanas após a emergência, para o híbrido Dina 933e.

\begin{tabular}{|c|c|c|c|c|c|c|}
\hline \multirow{2}{*}{$\begin{array}{l}\text { Incidências de } \\
\text { enfezamento* }\end{array}$} & \multicolumn{6}{|c|}{ Populações de $D$. maidis* } \\
\hline & $2^{\mathrm{a}}$ semana & $3^{a}$ semana & $4^{\text {a }}$ semana & $5^{a}$ semana & $6^{a}$ semana & $7^{\mathrm{a}}$ semana \\
\hline & & & Deficientes $\mathrm{C}$ & rrelação/Pr & 5 & \\
\hline $5^{\text {a }}$ semana & $\begin{array}{l}r=-0.23 \\
P=0.4650\end{array}$ & $\begin{array}{l}F=-0.13 \\
P=0.6899\end{array}$ & $\begin{array}{l}r=-0.35 \\
P=0.2600\end{array}$ & $\begin{array}{l}\mathrm{r}=-0.12 \\
\mathrm{P}=0.7164\end{array}$ & - & - \\
\hline $6^{\mathrm{a}}$ semana & $\begin{array}{l}\mathrm{r}=0.43 \\
\mathrm{P}=0.1555\end{array}$ & $\begin{array}{l}\mathrm{r}=-0.01 \\
\mathrm{P}=0.9846\end{array}$ & $\begin{array}{l}\mathrm{F}=-0.15 \\
\mathrm{P}=0.6318\end{array}$ & $\begin{array}{l}\mathrm{F}=-0.13 \\
\mathrm{P}=0.6882\end{array}$ & $\begin{array}{l}\mathrm{r}=0.03 \\
\mathrm{P}=0.9320\end{array}$ & - \\
\hline $7^{\mathrm{a}}$ semana & $\begin{array}{l}\mathrm{r}=0.50 \\
\mathrm{P}=0.0928\end{array}$ & $\begin{array}{l}\mathrm{r}=-0.10 \\
\mathrm{P}=0.7561\end{array}$ & $\begin{array}{l}\mathrm{r}=-0.22 \\
\mathrm{P}=0.4900\end{array}$ & $\begin{array}{l}\mathrm{r}=-0.19 \\
\mathrm{P}=0.5533\end{array}$ & $\begin{array}{l}\mathrm{r}=-0.01 \\
\mathrm{P}=0.9852\end{array}$ & $\begin{array}{l}\mathrm{r}=-0.31 \\
\mathrm{P}=0.5415\end{array}$ \\
\hline $8^{\mathrm{a}}$ semana & $\begin{array}{l}\mathrm{I}=0.3215 \\
\mathrm{P}=0.3989\end{array}$ & $\begin{array}{l}\mathrm{F}=0.20 \\
\mathrm{P}=0.6046\end{array}$ & $\begin{array}{l}\mathrm{r}=-0.08 \\
\mathrm{P}=0.8373\end{array}$ & $\begin{array}{l}r=-0.40 \\
\mathrm{P}=0.2784\end{array}$ & $\begin{array}{l}r=-0.39 \\
\mathrm{P}=0.2933\end{array}$ & $\begin{array}{l}\mathrm{r}=-0.70 \\
\mathrm{P}=0.1189\end{array}$ \\
\hline $9^{\mathrm{a}}$ semana & $\begin{array}{l}\mathrm{r}=-0.55 \\
\mathrm{P}=0.2558\end{array}$ & $\begin{array}{l}\Gamma=-0.39 \\
P=0.4355\end{array}$ & $\begin{array}{l}r=-0.69 \\
P=0.1260\end{array}$ & $\begin{array}{l}\Gamma=-0.88 \\
P=0.0176\end{array}$ & $\begin{array}{l}\mathrm{r}=-0.93 \\
\mathrm{P}=0.0075\end{array}$ & $\begin{array}{l}\mathrm{r}=-0.39 \\
\mathrm{P}=0.7454\end{array}$ \\
\hline $10^{a}$ semana & $\begin{array}{l}\mathrm{r}=0.49 \\
\mathrm{P}=0.1022\end{array}$ & $\begin{array}{l}\mathrm{r}=0.30 \\
\mathrm{P}=0.3398\end{array}$ & $\begin{array}{l}\mathrm{r}=0.07 \\
\mathrm{P}=0.8314\end{array}$ & $\begin{array}{l}r=-0.13 \\
P=0.6667\end{array}$ & $\begin{array}{l}r=-0.07 \\
P=0.8265\end{array}$ & $\begin{array}{l}\mathrm{r}=-0.26 \\
\mathrm{P}=0.6110\end{array}$ \\
\hline $11^{\mathrm{a}}$ semana & $\begin{array}{l}r=0.25 \\
P=0.5052\end{array}$ & $\begin{array}{l}\mathrm{r}=-0.48 \\
\mathrm{P}=0.1881\end{array}$ & $\begin{array}{l}\mathrm{r}=-0.48 \\
\mathrm{P}=0.19\end{array}$ & $\begin{array}{l}r=-0.53 \\
P=0.1354\end{array}$ & $\begin{array}{l}r=-040 \\
P=0.2807\end{array}$ & $\begin{array}{l}\Gamma=0.98 \\
P=0.1154\end{array}$ \\
\hline $\begin{array}{l}\text { Incidência no } \\
\text { estádio } 7\end{array}$ & $\begin{array}{l}r=0.43 \\
P=0.1569\end{array}$ & $\begin{array}{l}\mathrm{r}=-0.08 \\
\mathrm{P}=0.7913\end{array}$ & $\begin{array}{l}r=-0.21 \\
P=0.5146\end{array}$ & $\begin{array}{l}r=-0.33 \\
P=0.2888\end{array}$ & $\begin{array}{l}r=-0.24 \\
P=0.4497\end{array}$ & $\begin{array}{l}r=-0.60 \\
P=0.2024\end{array}$ \\
\hline
\end{tabular}

* Semanas após a emergência. 
Tabela 6. Coeficientes de correlação (r) entre população de D. maidis e incidências dos enfezamentos vermelho e pálido em diferentes semanas após a emergência, para o híbrido XL-510.

\begin{tabular}{|c|c|c|c|c|c|c|}
\hline \multirow{2}{*}{$\begin{array}{l}\text { Incidências de } \\
\text { enfezamento* }\end{array}$} & \multicolumn{6}{|c|}{ Populações de D. maidis* } \\
\hline & $2^{\mathrm{a}}$ semana & $3^{\mathrm{a}}$ semana & $4^{\text {a }}$ semana & $5^{a}$ semana & $6^{a}$ semana & $7^{\mathrm{a}}$ semana \\
\hline & & & oeficientes $\mathrm{C}$ & rrelação/Pro & t & - \\
\hline \multirow[t]{2}{*}{$5^{a}$ semana } & $r=0.30$ & $\mathrm{r}=0.05$ & $\mathrm{r}=0.10$ & $\Gamma=0.43$ & - & - \\
\hline & $\mathrm{P}=0.7451$ & $P=0.6266$ & $\mathrm{P}=0.4421$ & & & \\
\hline \multirow[t]{2}{*}{$6^{\mathrm{a}}$ semana } & $r=0.09$ & $\Gamma=0.04$ & $\Gamma=0.2905$ & $\Gamma=0.24$ & $r=0.25$ & - \\
\hline & $\mathrm{P}=0.7618$ & $\mathrm{P}=0.8844$ & $\mathrm{P}=0.3355$ & $P=0.4244$ & $\mathrm{P}=0.4004$ & \\
\hline \multirow[t]{2}{*}{$7^{a}$ semana } & $r=-0.01$ & $r=0.04$ & $\mathrm{r}=0.46$ & $r=0.21$ & $\mathrm{r}=0.2726$ & $r=0.02$ \\
\hline & $\mathrm{P}=0.9865$ & $\mathrm{P}=0.8842$ & $\mathrm{P}=0.1075$ & $\mathrm{P}=0.4906$ & $\mathrm{P}=0.3674$ & $\mathrm{P}=0.9392$ \\
\hline \multirow[t]{2}{*}{$8^{\mathrm{a}}$ semana } & $r=-0.13$ & $\mathrm{r}=0.11$ & $\mathrm{r}=0.46$ & $r=0.04$ & $\mathrm{r}=0.17$ & $r=-0.12$ \\
\hline & $P=0.6667$ & $P=0.7064$ & $\mathrm{P}=0.1103$ & $P=0.9016$ & $\mathrm{P}=0.5790$ & $\mathrm{P}=0.6949$ \\
\hline \multirow[t]{2}{*}{$9^{\mathrm{a}}$ semana } & $r=-0.02$ & $r=0.07$ & $\mathrm{r}=0.43$ & $r=0.21$ & $r=0.30$ & $r=-0.01$ \\
\hline & $\mathrm{P}=0.9538$ & $\mathrm{P}=0.8016$ & $\mathrm{P}=0.1401$ & $\mathrm{P}=0.4862$ & $\mathrm{P}=0.3132$ & $\mathrm{P}=0.9726$ \\
\hline \multirow[t]{2}{*}{$10^{\mathrm{a}}$ semana } & $r=0.23$ & $\mathrm{r}=-0.08$ & $\mathrm{r}=0.41$ & $r=0.39$ & $r=0.46$ & $r=0.28$ \\
\hline & $\mathrm{P}=0.4435$ & $\mathrm{P}=0.7968$ & $\mathrm{P}=0.1603$ & $\mathrm{P}=0.1794$ & $\mathrm{P}=0.1093$ & $\mathrm{P}=0.3533$ \\
\hline \multirow[t]{2}{*}{$11^{\mathrm{a}}$ semana } & $\mathrm{r}=0.17$ & $\mathrm{r}=0.19$ & $\mathrm{r}=0.47$ & $r=0.26$ & $r=0.38$ & $r=0.11$ \\
\hline & $\mathrm{P}=0.5794$ & $\mathrm{P}=0.5285$ & $\mathrm{P}=0.0986$ & $\mathrm{P}=0.3819$ & $\mathrm{P}=0.1971$ & $\mathrm{P}=0.7227$ \\
\hline \multirow{2}{*}{$\begin{array}{l}\text { Incidência no } \\
\text { estádio } 7\end{array}$} & $\mathrm{r}=0.16$ & $\mathrm{r}=0.18$ & $\mathrm{r}=0.51$ & $r=0.27$ & $r=0.39$ & $\mathrm{r}=0.09$ \\
\hline & $\mathrm{P}=0.5970$ & $\mathrm{P}=0.5400$ & $P=0.0728$ & $\mathrm{P}=0.3684$ & $\mathrm{P}=0.1816$ & $\mathrm{P}=0.7503$ \\
\hline
\end{tabular}

* Semanas após a emergência.

Os resultados apresentados neste capítulo revelaram que os enfezamentos são doenças capazes de causar danos severos à cultura do milho, tanto na produção como na qualidade dos grãos. Estes resultados, em conjunto com a constatação de que muitos híbridos comerciais em uso no Brasil apresentam altos níveis de suscetibilidade (Oliveira, 1998), alertam para o perigo potencial de epidemias de enfezamento e indicam a necessidade de estudos visando alternativas de controle para essa doença. Os plantios tardios de milho, conhecidos como "safrinha", além de serem mais afetados devido à alta população de $D$. maidis nos meses de março e abril (Waquil et al., 1997), constituem-se 
em reservatórios de vetores e patógenos durante a estação seca do ano. Portanto, nas regiões onde essa prática é adotada, o risco da ocorrência de epidemias torna-se muito maior. 


\section{EFEITO DA ÉPOCA DE INOCULAÇÃO DE Spiroplasma kunkelii NA PRODUÇÃO DE PLANTAS DE MLHO}

\subsection{RESUMO}

O efeito de inoculações seriadas com Spiroplasma kunkelii foi avaliado no híbrido suscetivel XL-510, cultivado em condições de telado anti-afideos. As plantas foram inoculadas aos 10, 24, 38, 52 e 66 dias após a emergência (estádios 1, 2, 3, 5 e 6, respectivamente) por meio de 5 cigarrinhas (Dalbulus maidis) infectivas por planta. Parcelas não inoculadas foram utilizadas como testemunhas. Foram utilizadas parcelas com 9 plantas e 4 repetições por época de inoculação. Os insetos se tomaram infectivos através de aquisição em planta fonte e posterior latência por 23 dias, sendo utilizado um novo lote de insetos a cada inoculação. Avaliações dos sintomas foram feitas semanalmente e, após a colheita, avaliou-se produção, peso de 1000 grãos, tamanho de grãos, altura de plantas e número de espigas/planta. Os resultados mostraram que a altura das plantas não foi influenciada pela época de inoculação, entretanto, as plantas inoculadas precocemente (estádios 1 e 2) apresentaram maior número de espigas, porém improdutivas. Tanto a produção como a qualidade dos grãos foram mais severamente afetadas quanto mais precoce foi a inoculação. Em relação à testemunha, foram obtidas reduções de $64,49,53,26$ e $1 \%$ na produção e de $59,54,57,22$ e $0 \%$ no peso de 1000 grãos, para parcelas inoculadas nos estádios $1,2,3,5$ e 6, respectivamente. 


\subsection{INTRODUÇÃO}

O enfezamento pálido do milho é uma importante doença dessa cultura nos Estados Unidos, México e América Latina (Nault et al., 1979; Nault et al., 1981; Shurtleff, 1986). Na década de 70, foi descoberto que o agente causal dessa doença é um procarioto da classe Mollicutes, habitante do floema das plantas doentes (Chen \& Granados, 1970; Chen \& Liao, 1975; Williamson \& Whitcomb, 1975). Esse organismo recebeu o nome genérico de "spiroplasma", por sua morfologia espiralada (Davis \& Worley, 1973) e, posteriormente, o nome da espécie ficou conhecido como Spiroplasma kunkelii (Whitcomb et al., 1986). Ao contrário do fitoplasma, organismo associado ao enfezamento vermelho, S. kunkelii pode ser cultivado em meios sintéticos (Liao \& Chen, 1977; Lee \& Davis, 1984; Lee \& Davis, 1989). A cigarrinha do milho (Dalbulus maidis DeLong \& Wolcott) é o vetor do patógeno (Davis, 1974; Nault, 1980). Num estudo recente (Gussie et al., 1995), S. kunkelii foi encontrado em diferentes órgãos da planta (folhas, raízes e pendão) antes da expressão dos sintomas. Dessa forma, o patógeno pode ser adquirido por $D$. maidis antes que a doença se torne evidente no campo.

O controle do enfezamento pálido pode ser conseguido por meio de genótipos resistentes (Shurtleff, 1986), porém, foi constatado recentemente que muitos híbridos comerciais do Brasil são suscetíveis à essa doença (Oliveira, 1998). Medidas alternativas de controle têm sido tentadas, como por exemplo, alterações na densidade populacional e no movimento dos vetores por meio de diferentes espaçamentos de plantio, fertilização nitrogenada e uso de culturas intercalares. Entretanto, nenhuma dessas medidas tem apresentado efeitos pronunciados na redução da incidência do enfezamento pálido (Power, 1989; Castro et al., 1992).

Normalmente, os danos associados ao enfezamento pálido são bastante elevados, podendo chegar a 100\%, quando a infecção ocorre precocemente (Scott et al., 1977). Na Nicarágua, plantas de milho protegidas da infecção pelos agentes dos enfezamentos, durante os primeiros 40 dias da cultura, produziram três vezes mais quando comparadas com plantas não protegidas (Hruska \& Peralta, 1997). No Brasil, a doença vem atingindo níveis elevados e causando sérios prejuízos em função do plantio de híbridos suscetíveis (Oliveira, 1998). O problema do enfezamento pálido no Brasil 
tende a ser mais sério em plantios realizados tardiamente, nos meses de fevereiro e março, quando as fases iniciais da cultura coincidem com os períodos de elevada população do inseto vetor no campo (Waquil et al., 1997). Essa tendência em causar maiores danos em plantios tardios já havia sido observada desde o primeiro relato da doença (Altstatt, 1945).

O objetivo desse trabalho foi determinar o efeito da inoculação com S. kunkelii, em diferentes estádios de crescimento, sobre a altura e alguns componentes da produção do milho. 


\subsection{MATERIAL E MÉTODOS}

O híbrido de milho XL-510, suscetível ao enfezamento pálido, foi semeado em telado anti-afideos, no espaçamento de $1,0 \mathrm{~m}$ entre linhas e 0,2 $\mathrm{m}$ entre plantas. Foram realizadas adubações de plantio e de cobertura (30 dias após a emergência) com $50 \mathrm{~g}$ por metro linear da fórmula 4-14-8 e sulfato de amônio, respectivamente, de maneira bastante uniforme. Durante todo o ensaio, a irrigação foi feita por meio de um sistema de gotejamento. A temperatura no interior do telado foi registrada continuamente por meio de um termógrafo.

Os tratamentos foram constituídos por cinco inoculações controladas do agente causal do enfezamento pálido ( $S$. kunkelii), através de vetores infectivos. As inoculações foram iniciadas no $10^{\circ}$ dia e se estenderam até $066^{\circ}$ dia após a emergência, com intervalo de 14 dias entre elas. Cada inoculação, feita num determinado estádio fenológico da planta, correspondeu a um tratamento (Tabela 7).

Tabela 7. Épocas de inoculação de plantas de milho do híbrido XL-510 com Spiroplasma kunkelii para determinação dos efeitos em componentes da produção.

\begin{tabular}{ccc}
\hline \multirow{2}{*}{ Tratamento } & \multicolumn{2}{c}{ Inoculação } \\
\cline { 2 - 3 } & Dias após a emergência & Estádio fenológico* \\
\hline 1 & 10 & 1 \\
3 & 24 & 2 \\
4 & 38 & 3 \\
5 & 52 & 5 \\
6 & 66 & 6 \\
\hline
\end{tabular}

* Estádios fenológicos da planta de milho, segundo Fancelli \& Lima (1992).

Esses tratamentos foram aplicados em parcelas compostas por 9 plantas consecutivas na linha. Tais parcelas foram distribuidas aleatoriamente nas linhas de 
plantio, em 4 repetições. O delineamento experimental adotado foi o inteiramente casualizado, devido à homogeneidade ambiental do interior da estufa.

Os vetores infectivos utilizados em cada uma das inoculações foram obtidos a partir de plantas infectadas com $S$. kunkelii. Ninfas de $2^{\circ}$ e $3^{\circ}$ instar de $D$. maidis, criadas em milho sadio, foram confinadas, com o auxílio de uma tela fina, junto ao cartucho de uma planta de milho pipoca da variedade Zélia, com sintomas severos de enfezamento pálido (planta fonte). O período de aquisição foi de 4 dias, após o qual as ninfas permaneceram por 23 dias em plantas de milho sadias, para um período de latência do patógeno nos vetores (Nault, 1980). Todos esses procedimentos foram conduzidos no interior de câmaras de crescimento (Conviron, Controlled Environments Limited, Winnipeg, MB, Canadá) com temperatura ajustada para $26{ }^{\circ} \mathrm{C}$ e repetidos, com um novo lote de insetos, para cada uma das inoculações. Após o período de latência, os insetos foram imediatamente utilizados nas inoculações, realizadas com 5 insetos infectivos de D. maidis por planta, com o auxílio de "gaiolinhas" presas às folha. Em todos os tratamentos, cada "gaiolinha" foi instalada na última folha expandida. O tempo total de inoculação foi de 3 dias, após o qual os insetos foram eliminados com inseticida e a "gaiolinha" retirada das folhas. Após a inoculação, todas as plantas do tratamento foram pulverizadas com o inseticida sistêmico Monocrotophos, visando eliminar possíveis ovos deixados nas folhas.

As plantas fonte usadas pelos vetores para aquisição do patógeno foram obtidas por transmissões sucessivas, a partir de uma planta de milho pipoca da variedade Zélia infectada unicamente com S. kunkelii. A ausência de fitoplasma nestas plantas foi comprovada por testes de PCR. Para isso, foram utilizados os primers R16F2 e R16R2, universais para a amplificação de rDNA 16S de fitoplasmas (Lee et al., 1993). Cada uma das plantas fonte utilizadas foi submetida a um teste de PTA-ELISA modificado (Mowat \& Dawson, 1987), utilizando antisoro policlonal para S. kunkelii. Tal procedimento visou confirmar a infeç̧ão dessas plantas pelo agente do enfezamento pálido. Foram consideradas positivas no teste ELISA as plantas que apresentaram valores de absorbância no mínimo 2 vezes maior que o apresentado pelo controle sadio (Sutula et al., 1986). As reações foram avaliadas por meio de um leitor de ELISA S960 (Metertech, Taiwan) a $405 \eta$ m. Para cada inoculação realizada no telado, 5 plantas de milho pipoca 
da variedade Zélia, que exibe sintomas característicos de enfezamento pálido, também foram inoculadas e mantidas em casa de vegetação para observação de desenvolvimento dos sintomas. O objetivo desse procedimento foi verificar a infectividade dos vetores e a eficiência das inoculações.

As avaliações das plantas inoculadas foram feitas semanalmente, por meio dos sintomas exibidos. Na época da colheita, foram avaliados altura de plantas, número de espigas/planta, produção, peso de 1000 grãos e porcentagem de grãos de diferentes tamanhos para cada um dos tratamentos. Esta última variável foi obtida passando-se amostras de $200 \mathrm{~g}$ de grãos, provenientes de cada parcela, em peneiras com malhas de tamanhos decrescentes $(9,52 ; 8,73 ; 7,93$ e $7,14 \mathrm{~mm})$. Em seguida, foram pesados os grãos que ficaram retidos em cada peneira e aqueles que passaram pela peneira de 7,14 $\mathrm{mm}$, sendo os resultados transformados em porcentagem. 


\subsection{RESULTADOS}

Todas as plantas fonte utilizadas nas inoculações tiveram resultado positivo para S. kunkelii através do teste ELISA. Da mesma forma, todas as plantas de milho pipoca da variedade Zélia inoculadas e mantidas em casa de vegetação mostraram sintomas típicos de enfezamento pálido, indicando que os vetores utilizados estavam infectivos e que a metodologia utilizada nas inoculações foi adequada.

As plantas inoculadas no estádio 1 exibiram avermelhamento nas folhas inoculadas cerca de 30 dias após a inoculação. No entanto, sintomas mais típicos da doença, como estrias cloróticas, amarelecimento e avermelhamento nos bordos das folhas superiores, começaram a aparecer apenas 40 dias após a inoculação, no início do florescimento, e se tornaram mais intensos durante o enchimento dos grãos. Nas parcelas inoculadas no estádio 2 , os primeiros sintomas da doença manifestaram-se cerca de 40 dias após a inoculação, durante o início do enchimento dos grãos. Para as demais inoculações, os sintomas tornaram-se visíveis apenas do estádio 8 em diante (cerca de 90

dias após a emergência), na forma de amarelecimento e avermelhamento das folhas superiores.

A altura das plantas não foi significativamente afetada pelo patógeno. Plantas inoculadas no estádio 1 foram, em média, apenas $30 \mathrm{~cm}$ menores que aquelas inoculadas no estádio 6 (Figura 6A) e $22 \mathrm{~cm}$ menores que a testemunha não inoculada. As plantas não inoculadas atingiram, em média, $3,73 \mathrm{~m}$. Por outro lado, o número de espigas por planta foi bastante afetado. As plantas inoculadas nos dois primeiros estádios mostraram maior número de espigas quando comparadas com as inoculadas posteriormente (Figura 6B) e com as não inoculadas (média de 1,7 espigas por planta). Entretanto, essas espigas apresentaram-se menores e de produção bastante reduzida. 


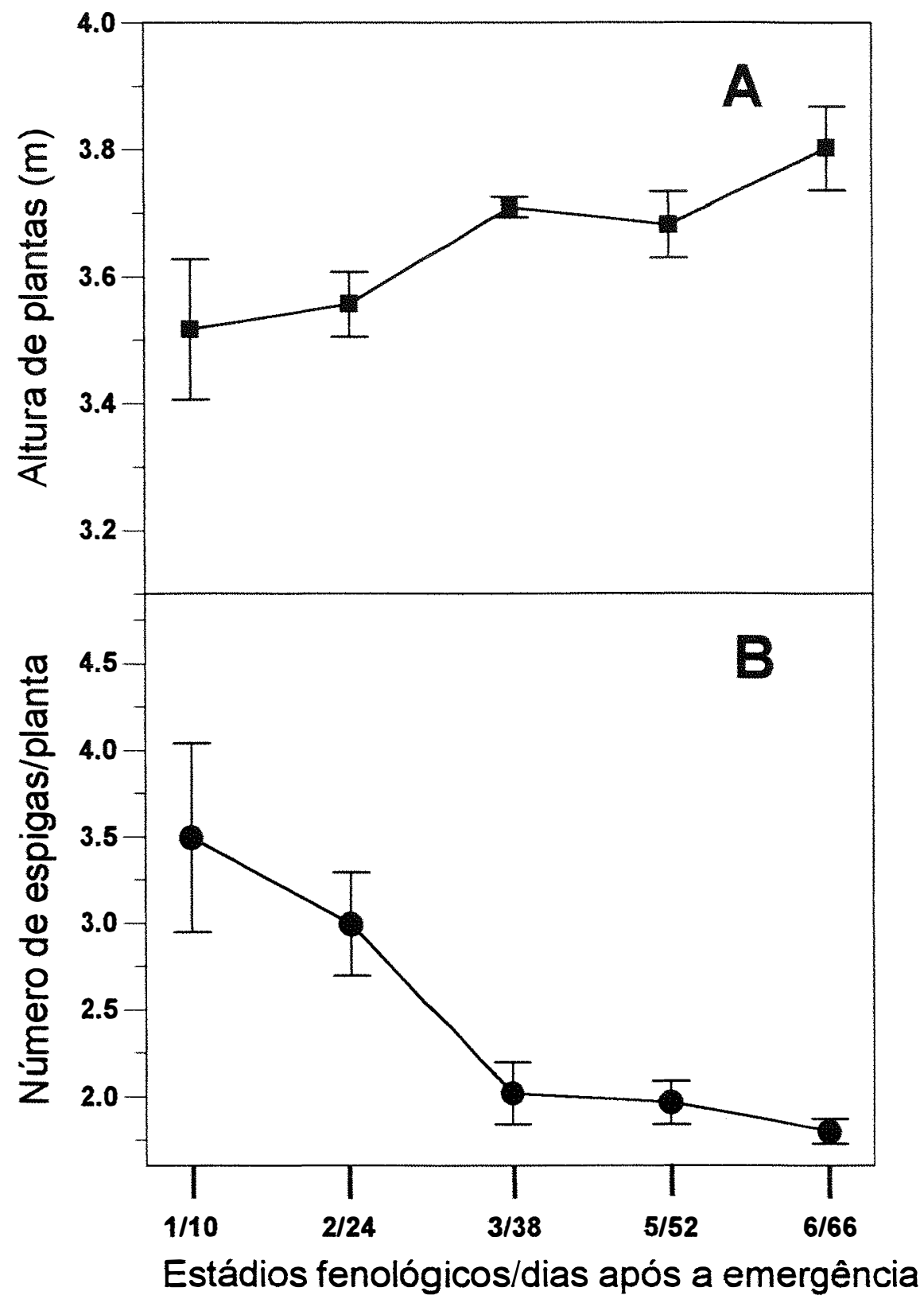

Figura 6. Efeito da época de inoculação do híbrido de milho XI-510 com Spiroplasma kunkelii na altura de plantas (A) e número de espigas/planta (B) (Cada ponto representa a média de 4 repetições. As barras representam o erro padrão).

As plantas que receberam as inoculações mais precocemente apresentaram os maiores danos na produção (Figura 7A) e no peso de 1000 grãos (Figura 7B). Os danos foram decrescentes à medida que se atrasaram as inoculações. Modelos polinomiais foram ajustados para essas relações por meio de análise de regressão (GLM-Procedure, 
SAS Institute, Cary, NC). A equação para danos na produção, comparada com a testemunha não inoculada (1.657 $\mathrm{g} /$ parcela), foi $\mathrm{Y}=59,53+0,33 \mathrm{X}-0,018 \mathrm{X}^{2}\left(\mathrm{R}^{2}=0,94\right)$, onde $\mathrm{Y}$ é a porcentagem de dano na produção e $\mathrm{X}$ é o dia após a emergência. Para o peso de 1000 grãos, comparado com a testemunha (316 g/1000 grãos), a equação foi $\mathrm{Y}=51,24+0,95 \mathrm{X}-0,027 \mathrm{X}^{2}\left(\mathrm{R}^{2}=0,95\right)$, onde $\mathrm{Y}$ é a porcentagem de dano no peso de 1000 grãos e $\mathrm{X}$ é o dia após a emergência. Os menores grãos foram verificados em plantas inoculadas nos estádios 1, 2 e 3 (Figura 8). Para esses três estádios, quase todos os grãos apresentaram diâmetro de 7,14 mm ou menor. Para plantas inoculadas nos estádios 5 e 6, mais que $90 \%$ dos grãos apresentaram diâmetro maior que $7,14 \mathrm{~mm}$. 


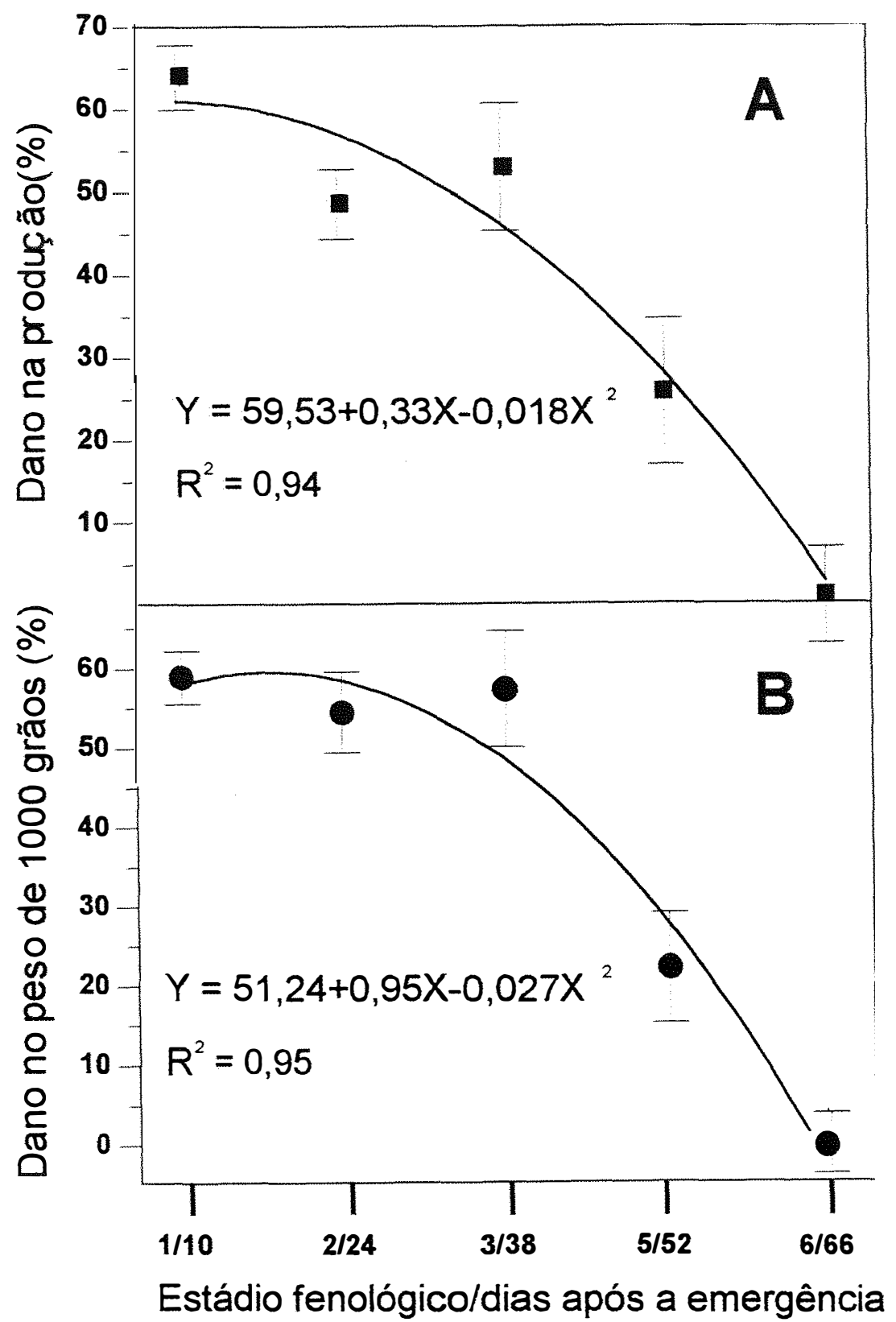

Figura 7. Efeito da época de inoculação do híbrido de milho XL-510 com Spiroplasma kunkelii na produção (A) e no peso de 1000 grãos (B) (Cada ponto representa a média de 4 repetições. As barras representam o erro padrão). 


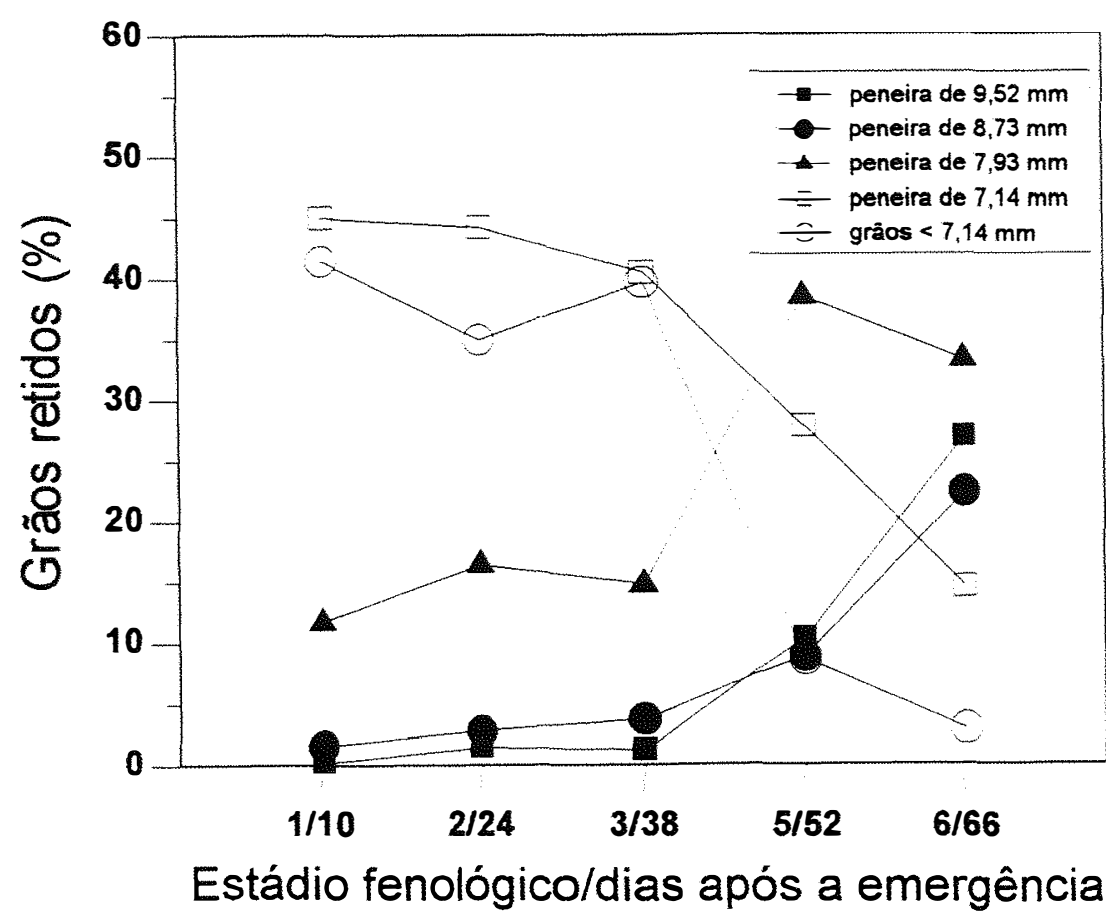

Figura 8. Efeito da época de inoculação do híbrido de milho XL-510 com Spiroplasma kunkelii no tamanho de grãos (Cada ponto representa a média de 4 repetições). 


\subsection{DISCUSSÃO}

Considerando as altas temperaturas observadas no interior do telado (média diurna de $27,6{ }^{\circ} \mathrm{C}$, variando de 18 a $36^{\circ} \mathrm{C}$, e média noturna de $21,6{ }^{\circ} \mathrm{C}$, variando de $17 \mathrm{a}$ $30{ }^{\circ} \mathrm{C}$ ), o período para o aparecimento dos sintomas foi maior que o encontrado por Nault (1980). Esse autor verificou que, em altas temperaturas (diurnas de $31{ }^{\circ} \mathrm{C}$ e noturnas de $25^{\circ} \mathrm{C}$ ), os primeiros sintomas apareceram cerca de 16 dias após a inoculação. Porém, um cultivar de milho doce extremamente suscetível foi usado pelo autor, o que pode ter contribuído para a redução no período de incubação. Outras explicações para o maior período de incubação encontrado, em comparação com o encontrado por aquele autor, podem ser levantadas, como, por exemplo, uma menor agressividade do isolado de $S$. kunkelii utilizado neste trabalho, as diferenças nas temperaturas diurnas e noturnas e as condições de cultivo do milho.

Os sintomas típicos de infeç̧ão por $S$. kunkelii se traduzem pelo aparecimento de estrias cloróticas na base das folhas (Nault, 1980; Shurtleff, 1986). Entretanto, esses sintomas ocorreram apenas em algumas plantas, e de forma bem amena, tendo sido mais comuns o amarelecimento e o avermelhamento de folhas superiores. Os sintomas de avermelhamento, considerados por diversos pesquisadores (por exemplo, Oliveira et al., 1998) como indicador de infecção por fitoplasma, não pode ser considerado como sintoma diagnóstico do enfezamento vermelho. Os resultados encontrados nesse trabalho confirmam a constatação de Nault (1980), segundo o qual, a sintomatologia dos enfezamentos dependem, além do agente causal, do genótipo do hospedeiro e das condições ambientes.

A redução na altura, relatada em plantas infectadas com S. kunkelii (Nault, 1980; Shurtleff, 1986; Hruska \& Peralta, 1997), não foi verificada. As plantas sofreram estiolamento no interior do telado, atingindo alturas superiores a $3,5 \mathrm{~m}$, o que provavelmente contribuiu para mascarar o efeito das inoculações na altura das plantas.

A equação que descreve os danos na produção mostrou, para o intervalo entre 10 e 38 dias, um ganho médio de $0,5 \%$ na produção para cada dia de atraso na infecção. Entretanto, para o intervalo entre 38 e 66 dias, esse ganho aumentou para 1,5\%, indicando que plantas infectadas mais tardiamente tendem a ser menos prejudicadas. 
Esse tipo de comportamento sugere uma semelhança do enfezamento pálido com doenças viróticas, nas quais os maiores danos geralmente estão associados a infecções precoces (Ross, 1969; Almeida et al., 1984). Resultados semelhantes já haviam sido relatados para esse patossistema por Scott et al. (1977), que encontraram danos de $100 \%$ sempre que o aparecimento dos sintomas precedeu o dia 52, a contar da semeadura. Após o dia 52, para cada dia de atraso, foi constatado um ganho de $1,82 \%$ na produtividade e, após o dia 107, a manifestação de sintomas não mostrou nenhum efeito na produção. Outro estudo, realizado mais recentemente na Nicarágua (Hruska \& Peralta, 1997), revelou que a exposição de plantas de milho à infeç̧ão natural pelos agentes do enfezamento durante os primeiros 40 dias após a emergência acarretou danos à produção da ordem de 70\%. Para os intervalos de exposição de 0-10, 10-20 e 20-30 dias, os danos foram de 37,21 e $28 \%$, respectivamente. Porém, quando a exposição foi realizada entre os dias 30 e 40 , a redução na produção foi de apenas $7 \%$.

Os resultados deste capítulo comprovaram que o enfezamento pálido é uma doença potencialmente destrutiva, podendo causar reduções na produção de mais de $60 \%$ quando a infecção ocorre precocemente. Ficou evidenciado, também, que outros componentes da produção, como o peso de 1000 grãos e o tamanho dos grãos, são bastante afetados pela doença.

Recentemente foi constatada a suscetibilidade de muitos híbridos, cultivados no Brasil, aos enfezamentos vermelho e pálido, o que tem provocado sérios prejuizos aos agricultores (Oliveira et al., 1998). Dessa maneira, torna-se necessário buscar alternativas para o controle dessa doença, até que um maior número de genótipos resistentes esteja disponivel. A constatação, obtida nesse capítulo, de que a infeç̧ão nos primeiros estádios provoca os maiores danos, indica que medidas de controle devem ser aplicadas nas fases iniciais da cultura, como já haviam sugerido Hruska \& Peralta (1997). Uma possibilidade seria o controle químico do inseto vetor, uma vez que aplicações mecanizadas de defensivos são possiveis no início da cultura do milho. Entretanto, há necessidade de se fazer um estudo da viabilidade econômica dessa medida. Outra alternativa seria programar a época de plantio, de tal forma a evitar a coincidência entre os estádios iniciais da cultura com o período de maior população de D. maidis no campo, que, para 
as condições brasileiras, foi determinado serem os meses de março e abril (Waquil et al., 1997). 


\section{MULTIPLICAÇÃO DE FITOPLASMA E ESPIROPLASMA E DANOS EM GENÓTIPOS RESISTENTE E SUSCETÍVEL DE MILHO}

\subsection{RESUMO}

Os híbridos de milho XL-510 e AG-951, respectivamente suscetível e resistente aos enfezamentos, foram experimentalmente inoculados, em condições de casa de vegetação, com fitoplasma, espiroplasma (Spiroplasma kunkelii) e fitoplasma + espiroplasma, por meio de insetos vetores (Dalbulus maidis) infectivos. As plantas foram inoculadas 10 dias após a emergência com 10 insetos infectivos por planta, ali mantidos por 4 dias. A presença dos patógenos em tecidos não inoculados foi avaliada por meio de testes ELISA e PCR respectivamente para espiroplasma e fitoplasma. A evolução dos sintomas foi avaliada semanalmente e a produção quantificada ao final do experimento. Foi possível detectar o espiroplasma e o fitoplasma somente no híbrido suscetível, indicando que no híbrido resistente não ocorreu multiplicação dos patógenos. Manifestação de sintomas e redução na produção foram registrados também somente para o híbrido suscetível. O fitoplasma mostrou-se mais agressivo que o espiroplasma, induzindo o aparecimento de sintomas mais precocemente e causando os maiores danos. 


\subsection{INTRODUÇÃO}

Os enfezamentos vermelho e pálido são doenças importantes na cultura do milho nas nossas condições, causando elevados prejuízos aos agricultores, principalmente em função do plantio de híbridos suscetíveis (Oliveira et al., 1998). A forma pálida do enfezamento é causada por um espiroplasma, Spiroplasma kunkelii (Davis et al., 1972) e a forma vermelha está associada a um fitoplasma (Granados, 1969). Ambos são organismos procariotos, habitantes do floema das plantas e transmitidos pela cigarrinha do milho Dalbulus maidis DeLong \& Wolcott (Nault, 1980).

Os plantios tardios, chamados de "safrinha", são, geralmente, mais afetados por essas doenças, em função da ocorrência de altas populações do vetor durante os meses de março e abril (Waquil et al., 1997). Dessa forma, uma das medidas de controle preconizadas consiste em evitar este tipo de plantio. No entanto, o milho "safrinha" é uma prática amplamente adotada nas principais regiões produtoras do Brasil, respondendo por cerca de $12 \%$ da produção brasileira de milho (Garcia, 1997). Assim, o uso de híbridos resistentes tem sido a forma de controle mais recomendada para minimizar os prejuízos causados pelas duas formas do enfezamento (Pereira, 1997).

Os híbridos têm sido considerados resistentes por apresentarem menores índices de incidência da doença, quando comparados com híbridos suscetíveis. No entanto, não existem informações a respeito do mecanismo envolvido na resistência, nem se os chamados híbridos resistentes restringem a multiplicação dos patógenos (resistência verdadeira) ou se permitem a multiplicação destes agentes e não mostram sintomas e redução na produção (tolerância).

Buscando-se estabelecer uma relação entre a reação de resistência/suscetibilidade de híbridos com multiplicação dos patógenos, expressão de sintomas e produção, plantas de milho foram inoculadas com fitoplasma e espiroplasma isoladamente e em conjunto. 


\subsection{MATERIAL E MÉTODOS}

Os híbridos de milho, XI-510 (suscetivel) e AG-951 (resistente), foram semeados em vasos ( 1 planta/vaso) contendo 81 de um substrato esterilizado, constituído por solo, areia e matéria orgânica e mantidos em telado. Dez dias após a emergência, as plantas foram inoculadas por meio de insetos vetores (D. maidis) infectivos, segundo os tratamentos: (1) testemunha (D. maidis não infectivos), (2) espiroplasma, (3) fitoplasma e (4) espiroplasma + fitoplasma. As inoculações foram feitas por meio de confinamento de 10 insetos em cada planta, com o auxílio de cilindros plásticos. As inoculações correspondentes ao tratamento 4, foram realizadas com 5 insetos infectivos com espiroplasma e 5 insetos infectivos com fitoplasma, uma vez que é dificil a obtenção de insetos infectivos com ambos os patógenos simultaneamente (Maramorosch, 1958). Esses tratamentos foram aplicados em 8 plantas de cada híbrido, sendo cada planta considerada como uma repetição. Os insetos infectivos foram obtidos segundo a metodologia descrita por Nault (1980). Ninfas de $2^{\circ}$ e $3^{\circ}$ instar de D. maidis, criadas em plantas de milho sadias, foram confinadas, usando uma espécie de saco de tela fina, junto ao cartucho de plantas de milho pipoca (variedade Zélia) com sintomas de infecção por espiroplasma ou por fitoplasma (plantas fonte). Previamente foi constatado, por meio de ELISA e PCR, que essas plantas não apresentavam infecção mista. O período de aquisição foi de 4 dias, após o qual as ninfas permaneceram por 23 dias em plantas sadias de milho, correspondendo ao período de latência dos patógenos nos vetores. Todos esses procedimentos foram conduzidos no interior de câmaras de crescimento (Conviron, Controlled Environments Limited, Winnipeg, MB, Canadá), com temperatura ajustada para $26{ }^{\circ} \mathrm{C}$ e $12 \mathrm{~h}$ de luz $/ 12 \mathrm{~h}$ de escuro. Após o período latente, os insetos foram imediatamente confinados, durante 4 dias, nas plantas a serem inoculadas e, em seguida, eliminados com inseticida. Todas as plantas do ensaio foram pulverizadas com uma mistura de inseticidas sistêmico e de contato, a cada 10 dias, para evitar a presença de cigarrinhas. Durante todo o ensaio, foram realizadas adubações de manutenção através de rega do solo com solução de macro e micronutrientes. A temperatura no interior do telado foi registrada por um termógrafo. 
O aparecimento dos sintomas foi registrado semanalmente e, após a colheita, avaliou-se produção e altura de plantas. Amostras foliares das plantas inoculadas foram coletadas, com a finalidade de detectar os patógenos no tecido vegetal. Para a deteç̧ão do espiroplasma, foi empregado o teste PTA-ELISA (Mowat \& Dawson, 1987) em todas as plantas inoculadas com esse patógeno, utilizando antisoro policlonal. Foram consideradas positivas todas as plantas com valor de absorbância no mínimo 2 vezes maior que o controle negativo (Sutula et al., 1986). As reações foram avaliadas através de leitor de ELISA S960 (Metertech, Taiwan) a 405 ๆm. Para a deteç̧ão do fitoplasma, foram amostradas, ao acaso, 3 plantas em cada tratamento. Nessas plantas, foram coletadas porções de limbo e da nervura central das folhas superiores. Tais amostras foram submetidas ao teste da Reação em Cadeia da Polimerase (PCR), utilizando-se os "primers" R16F2 e R16R2 (Lee et al., 1993). Após a análise dos produtos de PCR em gel de agarose, considerou-se positivas as amostras que apresentaram bandas de 1,2 Kb. 


\subsection{RESULTADOS E DISCUSSÃO}

O híbrido suscetivel mostrou os primeiros sintomas, nas plantas inoculadas com fitoplasma e fitoplasma + espiroplasma, cerca de 30 dias após a inoculação. Estes sintomas apareceram como avermelhamento nas margens das folhas superiores, seguindo-se o amarelecimento internerval dessas folhas e posterior avermelhamento da folha toda. As plantas inoculadas com o espiroplasma manifestaram sintomas apenas 60 dias após a inoculação, na forma de amarelecimento internerval das folhas superiores. Em seguida, essas folhas apresentaram diferentes níveis de avermelhamento, tornando-se muito semelhantes às plantas inoculadas com o fitoplasma. Estes resultados concordam, em parte, com aqueles obtidos por Nault (1980). Este autor verificou que plantas infectadas com fitoplasma mostraram sintomas antes daquelas inoculadas com espiroplasma, porém, os períodos de incubação obtidos por esse autor foram bem menores que os observados no presente ensaio. Possivelmente, as baixas temperaturas (médias diurna/noturna $=22 / 14{ }^{\circ} \mathrm{C}$ ) registradas no interior do telado, durante $\mathrm{o}$ desenvolvimento vegetativo do milho nesse ensaio, tenham contribuído para aumentar os períodos de incubação. Os sintomas de estrias cloróticas nas folhas, considerados típicos de infeç̧ão por espiroplasma, não foram observados nas plantas inoculadas com esse patógeno. Mesmo nessas plantas, o avermelhamento foi o sintoma mais evidente, confirmando a constatação de Nault (1980), segundo o qual, os sintomas dos enfezamentos dependem, além do agente causal, das condições ambientes e do genótipo do hospedeiro.

Os sintomas apareceram em aproximadamente $65 \%$ das plantas inoculadas no híbrido suscetível. Espiroplasma foi detectado em cerca de $55 \%$ das plantas inoculadas com este patógeno, enquanto que fitoplasma foi constatado em $100 \%$ das plantas amostradas, previamente inoculadas com este agente. Nenhuma planta do híbrido resistente exibiu sintoma de enfezamento, não sendo detectada a presença de patógenos em nenhuma delas (Tabela 8). Estes resultados evidenciaram que não houve multiplicação de espiroplasma e fitoplasma no híbrido resistente, indicando que a ausência de sintomas nestas plantas está possivelmente ligada à resistência e não à tolerância. 
Tabela 8. Manifestação de sintomas e detecção de fitoplasma e de espiroplasma em genótipos suscetível e resistente de milho.

\begin{tabular}{lccc}
\hline Tratamentos & $\begin{array}{c}\text { Sintomas } \\
\text { (ELISA) }\end{array}$ & $\begin{array}{c}\text { Deteção do espiroplasma } \\
\text { Testemunha }\end{array}$ & $\begin{array}{c}\text { Detecção do fitoplasma } \\
\text { (PCR) }\end{array}$ \\
Espiroplasma & $0 / 8^{*}$ & Híbrido XL-510 (suscetível) & N. D. ** D. \\
Fitoplasma & $6 / 8$ & $6 / 8$ & $0 / 3$ \\
Espiropl. + Fitopl. & $5 / 8$ & $0 / 8$ & $3 / 3$ \\
& $5 / 8$ & $3 / 8$ & $3 / 3$ \\
Testemunha & & Híbrido AG-951 (resistente) & \\
Espiroplasma & $0 / 8$ & $\mathrm{~N} . \mathrm{D}$. & $\mathrm{N} . \mathrm{D}$. \\
Fitoplasma & $0 / 8$ & $0 / 8$ & $0 / 3$ \\
Espiropl. + Fitopl. & $0 / 8$ & $0 / 8$ & $0 / 3$ \\
\hline
\end{tabular}

*Plantas positivas/plantas testadas.

**N. D. = não determinado.

A produção das plantas do híbrido suscetível foi reduzida significativamente pelo fitoplasma (Tabela 9). Neste caso, a produção chegou a ser reduzida em cerca de $70 \%$, quando o fitoplasma foi inoculado isoladamente, e em aproximadamente $50 \%$, quando fitoplasma foi inoculado juntamente com o espiroplasma. Inoculações feitas somente com espiroplasma mostraram que o patógeno reduziu a produção de grãos, porém esta redução não chegou a ser significativa em relação à produção de plantas não inoculadas. A produção do híbrido resistente e a altura das plantas de ambos os híbridos não foi influenciada por nenhum dos patógenos (Tabela 9). Estes resultados revelaram que o fitoplasma foi mais agressivo que o espiroplasma, concordando com relatos de Nault (1980), o qual também verificou que um isolado de fitoplasma foi mais agressivo que o espiroplasma, provocando drástica redução na altura de plantas e causando, inclusive, a morte de plantas de uma variedade suscetível de milho doce, quando mantidas em altas temperaturas. Da mesma forma, Oliveira et al. (1998) observaram danos de $100 \%$ em plantio comercial de milho que apresentava incidência de $100 \%$ de 
enfezamento vermelho e $16 \%$ de enfezamento pálido. Estes relatos reforçam a evidência, encontrada neste trabalho, de que o fitoplasma é mais prejudicial à cultura do milho que o espiroplasma.

Tabela 9. Efeito do fitoplasma e do espiroplasma, isolada e conjuntamente, na produção e na altura de plantas de genótipos suscetível e resistente de milho.

\begin{tabular}{lcccc}
\hline Tratamentos & \multicolumn{2}{c}{ Híbrido XL-510 (suscetivel) } & \multicolumn{2}{c}{ Híbrido AG-951 (resistente) } \\
\cline { 2 - 5 } & Altura de plantas (m) & Produção (g/planta) & Altura de plantas (m) & Produção (g/planta) \\
\hline Testemunha & $1,77 \mathrm{a}$ & $66,87 \mathrm{a}$ & $2,08 \mathrm{a}$ & $67,35 \mathrm{a}$ \\
Espiroplasma & $1,84 \mathrm{a}$ & $53,17 \mathrm{ab}$ & $2,03 \mathrm{a}$ & $53,50 \mathrm{a}$ \\
Fitoplasma & $1,80 \mathrm{a}$ & $20,50 \mathrm{c}$ & $1,98 \mathrm{a}$ & $56,07 \mathrm{a}$ \\
Espiropl. + Fitopl. & $1,98 \mathrm{a}$ & $32,48 \mathrm{bc}$ & $1,93 \mathrm{a}$ & $53,92 \mathrm{a}$ \\
& c.V. $=13,80 \%$ & c.V. $=30,81 \%$ & c.V. $=\mathbf{7}, 21 \%$ & c.V. $=23,26 \%$ \\
& DMS $=0,35 \mathrm{~m}$ & DMS $=23,64 \mathrm{~g}$ & DMS $=0,19 \mathrm{~m}$ & DMS $=19,12 \mathrm{~g}$ \\
\hline
\end{tabular}

*Valores obtidos com as plantas que apresentaram sintomas.

Médias seguidas de mesma letra, nas colunas, não diferem entre si pelo teste de Tukey a $\mathbf{5 \%}$. 


\section{CONCLUSÕES}

De acordo com os resultados obtidos neste trabalho, foi possivel concluir que:

- Os enfezamentos do milho causaram danos na produção e na qualidade dos grãos de híbridos suscetiveis de até $50 \%$ e $40 \%$, respectivamente, em condições naturais de infecção.

- Os maiores danos na produção e na qualidade dos grãos estiveram associados à infecções precoces, tanto em condições naturais de infecção, como em plantas inoculadas experimentalmente.

- A incidência de enfezamento, avaliada no estádio de grãos pastosos, e a área abaixo da curva de progresso da doença (AACPD) foram boas variáveis para estimativas de danos.

- Não houve correlação positiva entre população do vetor e níveis de incidência dos enfezamentos em condições naturais de infecção.

- Os sintomas de estrias cloróticas na base das folhas foram causados pelo espiroplasma. Entretanto, os sintomas de avermelhamento e/ou amarelecimento foliar e proliferação de espigas podem ser causados por ambos os patógenos.

- O hibrido resistente aos enfezamentos não permitiu a multiplicação dos patógenos e não teve a produção afetada. O híbrido suscetivel permitiu a multiplicação dos patógenos e apresentou redução na produção. 


\section{REFERÊNCIAS BIBLIOGRÁFICAS}

AGRIOS, G.N. Plant diseases caused by prokariotes: bacteria and mollicutes. In: AGRIOS, G.N. (Ed.). Plant Pathology. 4.ed. San Diego: Academic Press, 1997. cap. 12 , p. $407-470$.

ALIVIZATOS, A.S. Isolation and culture of corn stunt spiroplasma in serum-free medium. Journal of Phytopathology, v.122, p. 68-75, 1988.

ALIVIZATOS, A.S.; MARKHAM, P.G. Acquisition and transmission of corn stunt spiroplasma by its leafhopper vector Dalbulus maidis. Annals of Applied Biology, v. 108, p. 535-544, 1986.

ALMEIDA, L.D.; PEREIRA, J.C.V.N.A.; RONZELLI JR.; P.; COSTA, A.S. Avaliação de perdas causadas pelo mosaico dourado do feijoeiro (Phaseolus vulgaris L.) em condições de campo. Fitopatologia Brasileira, v. 9, p.213-219, 1984.

ALMEIDA, T.C. Utilização do milho e do sorgo no Brasil. In: BÜLL, L. T.; CANTARELLA, H. (Ed). Cultura do milho: fatores que afetam a produtividade. Piracicaba: Associação Brasileira para Pesquisa da Potassa e do Fosfato, 1993. cap. 2, p. 11-21.

ALtSTATt, G.E. A new corn disease in the Rio Grande valley. Plant Disease Reporter, v.29, p.533-534, 1945. 
ANUÁRIO ESTATÍSTICO DO BRASIL - 1993, v.55, p.3-39, 1995.

AYERS, J.E.; NELSON, R.R.; CASTOR, L.L.; BLANCO, M.H. Yield losses in corn caused by Helminthosporium maydis race T. Plant Disease Reporter, v.60, p. 331-335, 1976.

BAJET, N.B.; RENFRO, B.L. Occurrence of corn stunt spiroplasma at different elevations in Mexico. Plant Disease, v.73, p. 926-930, 1989.

BEDENDO, I.P. Micoplasmas e espiroplasmas. In: BERGAMIN FILHO, A., KIMATI, H., AMORIM, L. (Ed.) Manual de fitopatologia: princípios e conceitos. 3.ed. São Paulo: Agronômica Ceres, 1995. Cap.9, p. 202-210.

BEDENDO, I.P., DAVIS, R.E.; DALLY, E.L. Molecular evidence for the presence of maize bushy stunt phytoplasma in corn in Brazil. Plant Disease, v.81, p.957, 1997.

BERGAMIN FILHO, A. Avaliação de danos e perdas. In: BERGAMIN FILHO, A., KIMATI, H., AMORIM, L. (Ed.) Manual de fitopatologia: princípios e conceitos. 3.ed. São Paulo: Agronômica Ceres, 1995. cap.33, p. 672-690.

BERGAMIN FILHO, A.; AMORIM, L. Avaliação de perdas causadas pelas doenças. Summa Phytopathologica, v. 17, p.57-67, 1991.

BERGAMIN FILHO, A.; AMORIM, L. Doenças de plantas tropicais: epidemiologia e controle econômico. São Paulo: Agronômica Ceres, 1996. 299p.

BERGAMIN FILHO, A.; CARNEIRO, S.M.T.P.G.; GODOY, C.V.; AMORIM, L.; BERGER, R.D.; HAU, B. Angular leaf spot of Phaseolus beans: relationships between disease, healthy leaf area, and yield. Phytopathology, v.87, p.506-515, 1997. 
BERGAMIN FILHO, A.; LOPES, D.B.; AMORIM. L.; GODOY, C.V.; BERGER, R.D. Avaliação de danos causados por doenças em plantas. Revisão Anual de Patologia de Plantas, v.3, p.133-184, 1995.

BERGER, R.D. The analysis of te effects of control measures on the development of epidemics. In: KRANZ, J.; ROTEM, J. (Eds.). Experimental techniques in plant disease epidemiology. Heidelberg: Springer-Verlag, 1988. Cap. 9, p. 137151.

BHIRUD, K.M.; PITRE, H.N. Bioactivity of systemic insecticides in corn: relationships to leafhopper vector control and corn stunt disease incidence. Journal of Economic Entomology, v.65, p.1134-1140, 1972.

BISHT, I.S.; AGRAWAL, R.C. Modeling the relationship between purple blotch and yield loss in garlic and effect of leaf damage on bulb yield. Annals of Applied Biology, v. 125, p.293-300, 1994.

BRADFUTE, O.E; TSAI, J.H.; GORDON, D.T. Corn stunt spiroplasma and viruses associated with a maize disease epidemic in southern Florida. Plant Disease, v. 65, p.837-841, 1981.

BROSCIOUS, S.C.; PATAKY, J.K.; KIRBY, H.W. Quantitative relationship between yield and foliar diseases of alfafa. Phytopathology, v.77, p.887-892, 1987.

BURLEIGH, J.R.; ROELFS, A.P.; EVERSMEYER, M.G. Estimating damage to wheat caused by Puccinia recondita tritici. Phytopathology, v.62, p.944-946, 1972.

CAMPBELL, C.L.; MADDEN, L.V. Crop loss assesment and modeling. In: CAMPBELL, C.L.; MADDEN, L.V. (Ed.) Introduction to plant disease epidemiology. New York: John Wiley \& Sons, 1990. p.393-422. 
CARNEIRO, S.M.T.P.G.; AMORIM, L.; BERGAMIN FILHO, A. Avaliação de dano provocado pela mancha angular em feijoeiro: relação entre severidade, área foliar e componentes de produção. Fitopatologia Brasileira, v.22, p.427-431, 1997.

CASTRO, V.; RIVERA, C.; ISARD, S.A.; GÁMEZ, R.; FLETCHER, J.; IRWIN, M.E. The influence of weather and microclimate on Dalbulus maidis (homoptera: cicadellidae) flight activity and the incidence of diseases within maize and bean monocultures and bicultures in tropical America. Annals of Applied Biology, v.121, p. 469-482, 1992.

CHEN, T.A.; GRANADOS, R.R. Plant pathogenic mycoplasma-like organism: maintenance in vitro and transmission to Zea mays L. Science, v.167, p.1633$1636,1970$.

CHEN, T.A.; JIANG, X.F. Monoclonal antibodies against the maize bushy stunt disease agent. Canadian Journal of Microbiology, v.34, p.6-11, 1988.

CHEN, T.A.; LIAO, C.H.. Com stunt spiroplasma: isolation, cultivation, and proof of pathogenicity. Science, v. 188, p.1015-1017, 1975.

CHOUDHURY, M.M.; ROSENKRANZ, E. Differential transmission of Mississippi and Ohio com stunt agents by Graminella nigrifons. Phytopathology, v.63, p.127$133,1973$.

COSTA, A.S.; KITAJIMA, E.W.; ARRUDA, S.C. Moléstias de vírus e de micoplasma do milho em São Paulo. Revista da Sociedade Brasileira de Fitopatologia, v.4, p.39-41, 1971.

DAVIS, M.J.; TSAI, J.H.; McCOY, R.E. Isolation of the com stunt spiroplasma from maize in Florida. Plant Disease, v. 68, p.600-604, 1984. 
DAVIS, R.E. Occurrence of a spiroplasma in corn stunt-infected plants in Mexico. Plant Disease Reporter, v.57, p.333-337, 1973.

DAVIS, R. E. Spiroplasma in com stunt-infected individuals of the vector leafhopper Dalbulus maidis. Plant Disease Reporter, v.58, p.1109-1112, 1974.

DAVIS, R.E. New perspectives on yellows diseases and their causal agents gained through molecular methods for pathogen detection and identification. Summa Phytopathologica, v.21, p. 86-87, 1995a.

DAVIS, R.E. Fitoplasmas: fitopatógenos procarióticos sem parede celular, habitantes de floema e transmitidos por artrópodes. Revisão Anual de Patologia de Plantas, v.3, p.1-27, 1995b.

DAVIS, R.E.; LEE, I.M. Cluster-specific polymerase chain reaction amplification of 16S rDNA sequences for detection and identification of mycoplasmalike organisms. Phytopathology, v.83, n.9, p.1008-1011, 1993.

DAVIS, R.E.; WORLEY, J.F. Spiroplasma: motile, helical microorganism associated with corn stunt disease. Phytopathology, v.63, p.403-408, 1973.

DAVIS, R.E.; WORLEY, J.F.; WHITCOMB, R.F.; ISHIMA, T.; STEERE, R.L. Helicoidal filaments produced by a mycoplasma-like organism associated with com stunt disease. Science, v.176, p.521-523, 1972.

DEELEY, J.; STEVENS, W.A.; FOX, R.T.V. Use of Diene's stain to detect plant diseases induced by mycoplasmalike organisms. Phytopathology, v.69, p.1169$1171,1979$. 
DIAS, J.A.C.S.; MIRANDA FILHO, H.S.; RAMOS, V.J.; COSTA, A.S.; IGUE, T. Produção de batata-semente Aracy com diferentes níveis de enrolamento. Fitopatologia Brasileira, v.9, p.203-211, 1984.

EDEN-GREEN, S.J. Detection of corn stunt spiroplasma in vivo by ELISA using antisera to extracts from infected corn plants (Zea mays). Plant Pathology, v. 31, p.289-297, 1982.

FANCELLI, A.L.; LIMA, U.A. Milho: produção, pré-processamento e transformação agroindustrial. Piracicaba: Coordenadoria da Indústria e do Comércio/FEALQ, 1992. 112 p. (Série extensão agroindustrial, 5).

FOLEGATTI, M.E.G.; LOPES, J.RS.; AMORIM, L.; SILVA, W.J.; SOLFERINO, O.B.; SILVA, H.P.; PEREIRA, O.A.P. Incidência de enfezamento do milho e população do vetor, Dalbulus maidis, em diferentes localidades e épocas de plantio, na safra 95/96. Fitopatologia Brasileira, v.22, p.347, 1997.

GARCIA, J.C. Evolução da área e produtividade do milho "safrinha" por estado. In: SEMINÁRIO SOBRE A CULTURA DO MILHO "SAFRINHA", 4, Assis, 1997. Anais. Assis: IAC/CDV, 1997. p.11 -14.

GORDON, D.T.; NAULT, L.R.; GORDON, N.H.; HEADY, S.E. Serological detection of corn stunt spiroplasma and maize rayado fino virus in field-colected Dalbulus spp. from Mexico. Plant Disease, v.69, p.108-111, 1985.

GRANADOS, R.R. Electron microscopy of plants and insect vectors infected with the corn stunt disease agent. Contrib. Boyce Tompsom Inst., v.24, p.173-187, 1969.

GRANADOS, R.R.; WHITCOMB, R.F. Transmission of corn stunt mycoplasma by the leafhopper Baldulus tripsaci. Phytopathology, v.61, p.240-241, 1971. 
GROGAN, C.O.; ROSENKRANZ, E.E. Genetics of host reaction to corn stunt virus. Crop Science, v. 8, p. 252-254, 1968.

GUSSIE, J.S.; FLETCHER, J.; CLAYPOOL, P.L. Movement and multiplication of Spiroplasma kunkelii in corn. Phytopathology, v. 85, p. 1093-1098, 1995.

HARRISON, N.A.; RICHARDSON, P.A.; TSAI, J.H.; EBBERT, M.A.; KRAMER, J.B. PCR assay for detection of the phytoplasma associated with maize bushy stunt disease. Plant Disease, v. 80, p. 263-269, 1996.

HORSFALL, J.G.; COWLING, E.B. Pathometry: the measurement of plant disease. In: HORSFALL, J. G.; COWLING, E. B. (Eds.). Plant disease an advanced treatise: How disease develops in populations. Vol.2. New York: Academic Press, 1978. p. 119-136.

HRUSKA, A.J.; GLADSTONE, S.M.; OBANDO, R. Epidemic roller coaster: maize stunt disease in Nicaragua. American Entomologist, v.42, p.248-252, 1996.

HRUSKA, A.J.; PERALTA, M.G. Maize response to corn leafhopper (homoptera: cicadellidae) infestation and achaparramiento disease. Journal of Economic Entomology, v. 90, p. 604-610, 1997.

JAMES, W.C. Assessment of plant disases losses. Annual Review of Phytopathology, v.12, p.27-48, 1974.

JONES, A.L.; WHITCOMB, R.F.; WILLIAMSON, D.L.; COAN, M.E. Comparative growth and primary isolation of spiroplasmas in media based on insect tissues culture formulations. Phytopathology, v. 67, p. 738-746, 1997.

KIRBY, R.S.; ARCHER, W.A. Diseases of cereal and forage crops in the United States in 1926. Plant Disease Reporter, v.53, p.110-228, 1927. 
KITAJMA, E.W.; COSTA, A.S. Microrganismos do tipo micoplasma associados a moléstias do tipo amarelo em algumas plantas cultivadas e ornamentais, no estado de São Paulo e no Distrito Federal. Fitopatologia Brasileira, v.4, p.317-327, 1979

KITAJIMA, E.W.; NAZARENO, N.R.X. Levantamento de vírus e mollicutes do milho, no estado do Paraná. Fitopatologia Brasileira, v.10, p.613-625, 1985.

LARGE, E.C. Measuring plant disease. Annual Review of Phytopathology, v.4, p. 9$28,1966$.

LASTRA, R.; TRUJILLO, G.E. Enfermedades del maiz en Venezuela causadas por virus y micoplasmas. Agronomia Tropical, v.26, p. 441-455, 1976.

LEE, I.-M.; DAVIS, R.E. New media for rapid growth of Spiroplasma citri and corn stunt spiroplasma. Phytopathology, v.74, p.84-89, 1984.

LEE, I.-M.; DAVIS, R.E. Serum-free media for cultivation of spiroplasmas. Canadian Journal of Microbiology, v.35, p. 1092-1099, 1989.

LEE, I.-M.; HAMMOND, R.W.; DAVIS, R.E.; GUNDERSEN, D.E. Universal amplification and analysis of pathogen 16S rDNA for classification and identification of mycoplasmalike organisms. Phytopathology, v.83, p.834-842, 1993.

LEGRAND, A.I.; POWER, A.G. Inoculation and acquisition of maize bushy stunt mycoplasma by its leafhopper vector Dalbulus maidis. Annals of Applied Biology, v. 125, p. 115-122, 1994.

LEZCANO, R.; MACHADO, V. Fitoplasmas y espiroplasmas de mais en el Paraguay. Fitopatologia Brasileira, v.22, p.347, 1997. 
LIAO, C.H.; CHEN, T.A. Culture of corn stunt spiroplasma in a simple medium. Phytopathology, v.67, p.802-807, 1977.

LIN, C.P.; CHEN, T.A. Monoclonal antibodies against the aster yellows agent. Science, v. 227, p. $1233-1235,1985$.

LOPES, M.T.V.C.; CAMARGO, L.E.A., FOLEGATTI, M.E.; LOPES, J.R.S. Freqüência de mollicutes associados ao enfezamento do milho em algumas localidades do estado de São Paulo. Fitopatologia Brasileira, v.22, p. 347, 1997.

MADDEN L.V.; NAULT. L.R. Differential pathogenicity of corn stunting mollicutes to leafhopper vectors in Dalbulus and Baldulus species. Phytopathology, v.73, p.1608-1614, 1983.

MADDEN, L.V.; CAMPBELL, C.L. Descriptions of virus disease epidemics in time and space. In: McLEAN, G.D.; GARRET, R.G.; RUESINK, W.G. (Eds.). Plant virus epidemics. New York: Academic Press, 1986. p.273-94.

MAGALHÃES, P.C.; DURÃES, F.O.M.; PAIVA, E. Fisiologia da planta de milho. Sete Lagoas: Empresa Brasileira de Pesquisa Agropecuária - EMBRAPA, 1995. 64p. (EMBRAPA. Circular Técnica, 20).

MAIN, C.E. Crop destruction - the raison d'être of plant pathology. In: HORSFALL, J.C.; COWLING, E.B. (Eds.). Plant disease an advanced treatise. Vol.2. New York: Academic Press, 1978. p.55-78.

MARAMOROSCH, $\mathrm{K}$. Cross protection between two strains of corn stunt virus in a insect vector. Virology, v.6, p.448-459, 1958. 
MASSOLA JÚNIOR, N.S.; KITAJIMA, E.W. Scanning electron microscopy and in situ immunolabelling of the corn stunt spiroplasma. Acta Microscopica, v.6, p.176$177,1997$.

MOWAT, W.P.; DAWSON, S. Detection of plant viruses by ELISA using crude sap extracts and unfractioned antisera. Journal of Virological Methods, v.15, p.233$247,1987$.

NAULT, L.R. Arthropod transmission of plant viruses: a new synthesis. Annals of the Entomological Society of America, v.90, p.521-541, 1997.

NAULT, L.R. Evolution of an insect pest: maize and the corn leafhopper, a case study. Maydica, v.35, p.165-175, 1990.

NAULT, L.R. Maize bushy stunt and corn stunt: a comparison of disease symptoms, pathogen host ranges, and vectors. Phytopathology, v.70, p.659-662, 1980.

NAULT, L.R.; GORDON, D.T.; CASTILLO LOAYZA, J. Maize virus and mycoplasma diseases in Peru. Tropical Pest Management, v.27, p.363-369, 1981.

NAULT, L.R.; GORDON, D.T.; GINGERY, R.E.; BRADFUTE, O; CASTILLO LOAYZA, J. Identification of maize viruses and Mollicutes and their potential insect vectors in Peru. Phytopathology, v.69, p.824-828, 1979.

NELSON, L.R.; SCOTT, G.E. Diallel analysis of resistance of corn (Zea mays L.) to corn stunt. Crop Science, v.13, p.162-164, 1973.

OLIVEIRA, E.; OLIVEIRA, A.C. Incidência da virose rayado fino e enfezamentos em milho em diferentes épocas de plantio. Fitopatologia Brasileira, v.23, p.330, 1998. 
OLIVEIRA, E.; WAQUIL, J.M.; FERNANDES, F.T.; PAIVA, E.; RESENDE, R.O.; KITAJIMA, E.W. "Enfezamento pálido" e "enfezamento vermelho" na cultura do milho no Brasil Central. Fitopatologia Brasileira, v.23, p.45-47, 1998.

OLIVEIRA, E.; WAQUIL, J.M.; PINTO, N.F.J.A. Doenças causadas por patógenos transmitidos por insetos: complexo enfezamento/mosaico. In: SEMINÁRIO SOBRE A CULTURA DO MILHO "SAFRINHA", 4, Assis, 1997. Anais. Assis: IAC/CDV, 1997. p.87-94.

OVERMAN, M.A.; KO, N.J.; TSAI, J.H. Identification of viruses and mycoplasmas in maize by use of light microscopy. Plant Disease, v. 76, p.318-322, 1992.

PARK, E.W.; LIM, S.M. Empirical estimation of the asymptotes of disease progress curves and the use of the Richards generalized rate parameters for describing disease progress. Phytopathlogy, v. 75, p. 786-791, 1985.

PEREIRA, O.A.P. Doenças do milho. In: KIMATI, H.; AMORIM, L.; BERGAMIN FILHO, A.; CAMARGO, L.E.A.; REZENDE, J.A.M. (Eds.). Manual de Fitopatologia - doenças das plantas cultivadas. vol 2. São Paulo: Agronômica Ceres, 1997. Cap.52, p. 538-555.

PINAZZA, L. A. Perspectivas da cultura do milho e do sorgo no Brasil. In: BÜLL, L. T.; CANTARELlA, H. (Ed.). Cultura do milho - fatores que afetam a produtividade. Associação Brasileira para pesquisa da potassa e do fosfato, Piracicaba, 1993. cap. 1, p. 1-10.

POWER, A.G. Influence of plant spacing and nitrogen fertilization in maize on Dalbulus maidis (homoptera: cicadellidae), vector of corn stunt. Environmental Entomology, v.18, p.494-498, 1989. 
POWER, A.G. Plant community diversity, herbivore movement, and an insecttransmited disease of maize. Ecology, v.68, p.1658-1669, 1987.

RAJU, B.C.; NYLAND, G. Enzyme-linked immunosorbent asay for the detection of corn stunt spiroplasma in plant and insect tissues. Current Microbiology, v.5, p. 101-104, 1981.

ROSS, J.P. Effect of time and sequence of inoculation of soybeans with Soybean Mosaic and Bean Mottle viruses on yield and seed characters. Phytopathology, v.59, p. 1404-1408, 1969.

SCHNEIDER, R.W.; WILLIAMS, R.J.; SINCLAIR, J.B. Cercospora leaf spot of cowpea: models for estimating yield loss. Phytopathology, v.66, p.384-388, 1976.

SCOTT, G.E.; ROSEKRANZ, E.E. Independent inheritance of corn stunt and maize dwarf mosaic in corn. Crop Science, v. 14, 104-106, 1974.

SCOTT, G.E.; ROSEKRANZ, E.E.; NELSON, L.R. Yield losses of corn due to corn stunt disease complex. Agronomy Journal, v.69, p.92-4, 1977.

SHANER, G.; FINNEY, R.E. The effect of nitrogen fertilization on the expression of slow-mildewing resistance in Knox wheat. Phytopathology, v.70, p.1183-1186, 1977.

SHURTLEFF, M.C. Compendium of corn diseases. 2 ed. St. Paul: American Phytopathological Society, 1986. 105 p.

SUTULA, C.L.; GILLET, J.M.; MORRISSEY, S.M.; RAMSDELL, D.C. Interpreting ELISA data and establishing the positive-negative threshold. Plant Disease, v.70, p.722-726, 1986. 
TENG, P.S. Crop loss assessment and pest management. St. Paul: APS Press, 1987. 270 p.

TSAI, J.H. Vector transmission of mycoplasmal agents of plants diseases. In: WHITCOMB, R.F.; TULLY, J.G. (Eds.). The mycoplasmas: Plant and insect mycoplasmas. Vol. III. New York: Academic Press, 1979. cap. 9, p.265-307.

ULLSTRUP, A.J. Corn diseases in the United States and their control. Washington, D.C.: USDA, 1978. 55p. (USDA. Agriculture Handbook, 199).

VANDERPLANK, J.E. Plant diseases: epidemics and control. New York: Academic Press, 1963. $349 \mathrm{p}$.

VEGA, F.E.; DAVIS, R.E.; BARBOSA, P.; DALLY, E.L.; PURCELL, A.H.; LEE, I.-M. Detection of a plant pathogen in a nonvector insect species by the polymerase chain reaction. Phytopathology, v.83, p. 621-624, 1993.

WAGGONER, P.E.; BERGER, R.D. Defoliation, disease and growth. Phytopathology, v.77, p. 393-398, 1987.

WAQUIL, J.M.; OLIVEIRA, E.; PINTO, N.F.J.A. Incidência de cigarrinha, enfezamento e viroses em milho. In: SEMINÁRIO SOBRE A CULTURA DO MILHO "SAFRINHA", 4, Assis, 1997. Anais. Assis: IAC/CDV, 1997. p. 87-94.

WAQUIL, J.M.; OLIVEIRA, E.; PINTO, N.F.J.A.; FERNANDES, F.T.; CORREIA, L.A. Viroses em milho - incidência e efeito na produção. Fitopatologia Brasileira, v.21, p.460-463, 1996.

WHITCOMB，R.F.; CHEN, T.A.; WILLIAMSON, D.L.; LIAO, C.; TULLY, J.G.; BOVE, J.M.; MOUCHES, C.; ROSE, D.L.; COAN, M.E.; CLARK, T.B. Spiroplasma kunkelii sp. nov.: characterization of the etiological agent of corn 
stunt disease. International Journal of Systematic Bacteriology, v.36, p.170$178,1986$.

WILLIAMSON, D.L.; WHITCOMB, R.F. Plant mycoplasmas: a cultivable spiroplasma causes corn stunt disease. Science, v.188, p.1018-1020, 1975. 